\title{
Post-Plasma Catalysis for Trichloroethylene Abatement with Ce-Doped Birnessite Downstream DC Corona Discharge Reactor
}

\author{
Grêce Abdallah ${ }^{1,2}{ }^{\mathbb{D}}$, Jean-Marc Giraudon ${ }^{1}$, Rim Bitar ${ }^{2}$, Nathalie De Geyter ${ }^{2}{ }^{\mathbb{D}}$, Rino Morent ${ }^{2}$ \\ and Jean-François Lamonier ${ }^{1, *(1)}$ \\ 1 Univ. Lille, CNRS, Centrale Lille, Univ. Artois, UMR 8181-UCCS-Unité de Catalyse et Chimie du Solide, \\ F-59000 Lille, France; grece_abdallah94@hotmail.com (G.A.); jean-marc.giraudon@univ-lille.fr (J.-M.G.) \\ 2 Research Unit Plasma Technology (RUPT), Department of Applied Physics, Faculty of Engineering and \\ Architecture, Ghent University, Sint-Pietersnieuwstraat 41 (B4), 9000 Ghent, Belgium; \\ Rim.Bitar@UGent.be (R.B.); Nathalie.DeGeyter@Ugent.be (N.D.G.); Rino.Morent@Ugent.be (R.M.) \\ * Correspondence: jean-francois.lamonier@univ-lille.fr
}

Citation: Abdallah, G.; Giraudon, J.-M.; Bitar, R.; Geyter, N.D.; Morent, R.; Lamonier, J.-F. Post-Plasma Catalysis for Trichloroethylene Abatement with Ce-Doped Birnessite Downstream DC Corona Discharge Reactor. Catalysts 2021, 11, 946. https://doi.org/10.3390/catal11080946

Academic Editor: Xin Tu

Received: 19 July 2021

Accepted: 3 August 2021

Published: 5 August 2021

Publisher's Note: MDPI stays neutral with regard to jurisdictional claims in published maps and institutional affiliations.

Copyright: (c) 2021 by the authors. Licensee MDPI, Basel, Switzerland. This article is an open access article distributed under the terms and conditions of the Creative Commons Attribution (CC BY) license (https:// creativecommons.org/licenses/by/ $4.0 /)$.
Abstract: Trichloroethylene (TCE) removal was investigated in a post-plasma catalysis (PPC) configuration in nearly dry air $(\mathrm{RH}=0.7 \%)$ and moist air $(\mathrm{RH}=15 \%)$, using, for non-thermal plasma (NTP), a 10-pin-to-plate negative DC corona discharge and, for PPC, $\mathrm{Ce}_{0.01} \mathrm{Mn}$ as a catalyst, calcined at $400{ }^{\circ} \mathrm{C}\left(\mathrm{Ce}_{0.01} \mathrm{Mn}-400\right)$ or treated with nitric acid $\left(\mathrm{Ce}_{0.01} \mathrm{Mn}-\mathrm{AT}\right)$. One of the key points was to take advantage of the ozone emitted from NTP as a potential source of active oxygen species for further oxidation, at a very low temperature $\left(100^{\circ} \mathrm{C}\right)$, of untreated TCE and of potential gaseous hazardous by-products from the NTP. The plasma-assisted $\mathrm{Ce}_{0.01} \mathrm{Mn}$-AT catalyst presented the best $\mathrm{CO}_{2}$ yield in dry air, with minimization of the formation of gaseous chlorinated by-products. This result was attributed to the high level of oxygen vacancies with a higher amount of $\mathrm{Mn}^{3+}$, improved specific surface area and strong surface acidity. These features also allow the promotion of ozone decomposition efficiency. Both catalysts exhibited good stability towards chlorine. $\mathrm{Ce}_{0.01} \mathrm{Mn}$-AT tested in moist air $(\mathrm{RH}=15 \%)$ showed good stability as a function of time, indicating good water tolerance also.

Keywords: post-plasma catalysis; non-thermal plasma; trichloroethylene; ozone decomposition; Ce-doped birnessite

\section{Introduction}

Trichloroethylene (TCE) is a chlorinated VOC commonly used in industry as a solvent and which acts as a degreaser in the semiconductor and metal industries [1-3]. Release of TCE into outdoor and indoor air can occur during degreasing operations and consumption of related products [2]. The International Agency for Research on Cancer (IARC) listed TCE as potentially carcinogenic (Group 2A) and a recent evaluation based on new data has proven that there is sufficient evidence to conclude that TCE is carcinogenic to humans (Group 1) [4]. Due to its adverse impacts on environmental and human health, TCE removal from waste gas streams is an issue of major concern. Conventional techniques, such as adsorption, thermal incineration or catalytic oxidation can been used for chlorinated VOC removal. However, the use of such techniques for the removal of diluted VOCs $(<1000$ ppmv) from waste gas is not energy-efficient [5-9].

In recent decades, post-plasma catalysis (PPC), resulting from the coupling of a nonthermal plasma (NTP) reactor with a catalytic reactor positioned downstream, has been recognized as an advanced oxidation process for removal of diluted VOCs from waste air $[10,11]$. Although NTP displays a high reactivity towards VOC removal at $20{ }^{\circ} \mathrm{C}$, the selectivity of this process for $\mathrm{COx}\left(\mathrm{CO}\right.$ and $\left.\mathrm{CO}_{2}\right)$ is poor and hazardous gaseous byproducts are formed. In the PPC configuration, catalytic reactions can take advantage of the 
NTP-emitted $\mathrm{O}_{3}$ as a potential source of active oxygen species, enabling further oxidation, at ambient or very low temperatures, of the NTP non-degraded parent VOC and gaseous hazardous by-products. The resulting hybrid technology therefore improves upon NTP and total oxidation catalysis in terms of selectivity, efficiency and energy cost.

The catalyst positioned after the plasma reactor should have specific characteristics, such as high efficiency in plasma-generated ozone decomposition, high oxygen mobility and high $\mathrm{CO}_{2}$ selectivity, coupled with an elevated resistance to chlorine. $\mathrm{MnO}_{2}$-based catalysts in particular have been studied for TCE removal in the PPC configuration because of their efficient ability to decompose ozone to provide surface active oxygen species for the decomposition of plasma-generated polychlorinated by-products [12,13]. However, the plasma-generated by-products are not fully decomposed into $\mathrm{CO}_{2}$ and the catalysts deactivate over time due to chlorine-induced deactivation. In order to promote the efficiency of the PPC process in terms of chlorinated VOC abatement, the catalyst efficiency should be improved.

Doping manganese oxides with $\mathrm{Ce}$, such as Ce-doped todorkite [14], $\alpha-\mathrm{MnO}_{2}$ [15], $\gamma-\mathrm{MnO}_{2}$ [16], $\mathrm{Mn}_{\mathrm{a}} \mathrm{O}_{\mathrm{x}}$ [17] and birnessite (layered $\mathrm{MnO}_{2}$ ) [18-21], has been found to lead to the enhancement of the catalytic performance in terms of ozone decomposition and the catalytic oxidation of various organic pollutants. Such enhancement has been explained by an improvement of the textural properties, a modification of the Mn average oxidation state and an increase of structural defects, e.g., oxygen vacancies due to the formation of crystal boundaries between $\mathrm{MnO}_{2}$ and $\mathrm{CeO}_{2}$. Furthermore, it has recently been reported $[22,23]$ that birnessite treated with nitric acid is a good candidate for ozone decomposition, especially in the presence of water, because of the increase of material hydrophobicity. Additionally, for abatement of VOC chlorination, catalysts with strong acidity could effectively prevent the chlorination $[24,25]$.

In this paper, TCE abatement was investigated in dry and humid air. The catalysts used in the PPC system was composed of Ce-doped birnessite $\left(\mathrm{Ce}_{0.01} \mathrm{Mn}\right.$; molar ratio $\mathrm{Ce} / \mathrm{Mn}=0.01$ ) and either treated with nitric acid, which met most criteria discussed above, or calcined at $400{ }^{\circ} \mathrm{C}$ for use as a reference. In order to increase the efficiency of the NTP-assisted catalyst for TCE total oxidation, particular attention was paid to regulating the ratio of the concentration of NTP-generated ozone to that of inlet TCE. The effect of humidity towards TCE abatement in plasma alone and in the PPC process was also investigated. Finally, the performance of the plasma-assisted catalysts for TCE abatement was correlated with the physico-chemical properties of the tested catalysts.

\section{Results and Discussion}

\subsection{Main Physicochemical Characteristics of the Fresh Materials}

The powder XRD patterns of the samples are shown in Figure 1. The $\mathrm{Ce}_{0.01} \mathrm{Mn}-400$ sample was poorly crystallized and exhibited four broad peaks centered at $12.2^{\circ}(001)$, $24.5^{\circ}(002), 37.0^{\circ}(110)$ and $66.2^{\circ}(110)$, which are characteristics of a turbostratic birnessite structure [26]. The XRD pattern of the $\mathrm{Ce}_{0.01} \mathrm{Mn}$-AT sample was ill-defined and presented diffraction peaks centered at $37.0^{\circ}$ and $66.2^{\circ}$. However, the two diffraction peaks (001) and (002) were no more visible in the powder XRD pattern of the $\mathrm{Ce}_{0.01} \mathrm{Mn}$-AT sample. This could have been related to the diminution of the number of layers stacked in the crystal after the acidic treatment. Indeed, when the coherent scattering domain size decreases, the intensity of the peaks decreases and their full width at half the maximum increases $[27,28]$.

The elemental compositions of the material after calcination and acid treatment are given in Table 1. The Ce/Mn atomic ratio for $\mathrm{Ce}_{0.01} \mathrm{Mn}-400$ was close to the expected value $(0.01)$ and it was slightly modified after acid treatment. After acid treatment, the Na and K contents decreased drastically; the $\mathrm{Na} / \mathrm{Mn}$ as well the $\mathrm{K} / \mathrm{Mn}$ ratio significantly dropped. This result can be partly explained by $\mathrm{Na}^{+}-\mathrm{H}^{+}$and $\mathrm{K}^{+}-\mathrm{H}^{+}$ion exchange reactions [22,23]. 


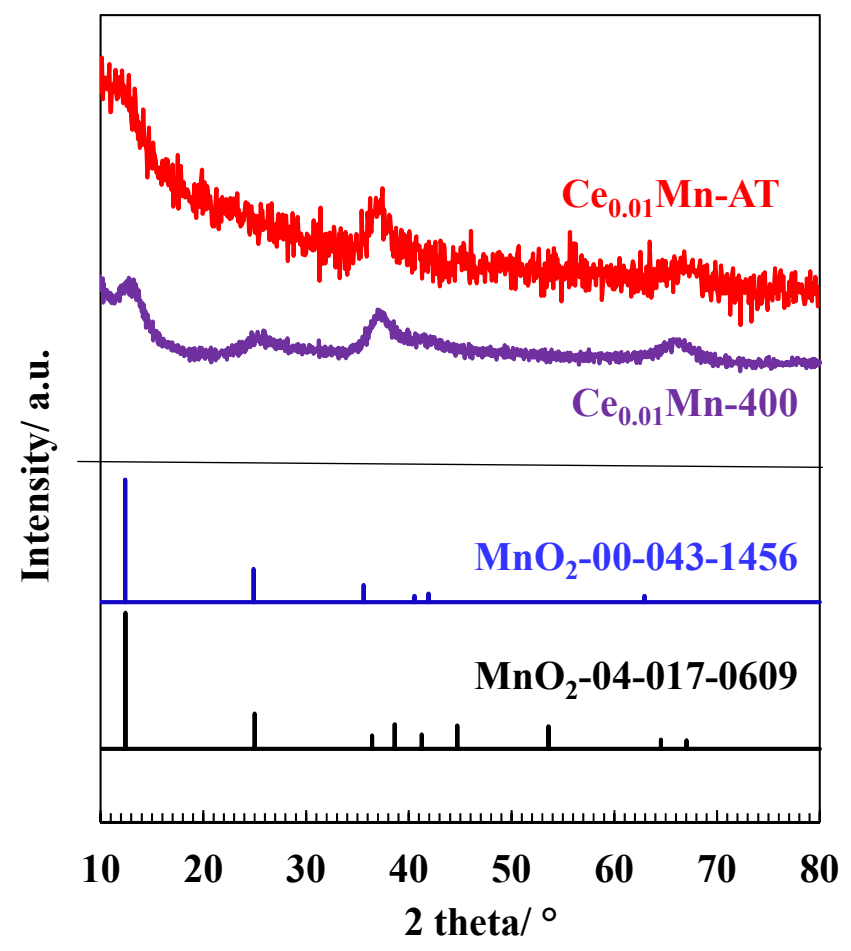

Figure 1. XRD patterns of the $\mathrm{Ce}_{0.01} \mathrm{Mn}-400$ and $\mathrm{Ce}_{0.01} \mathrm{Mn}-\mathrm{AT}$ samples.

Table 1. Weight composition and atomic ratio for the $\mathrm{Ce}_{0.01} \mathrm{Mn}-400$ and $\mathrm{Ce}_{0.01} \mathrm{Mn}-\mathrm{AT}$ samples.

\begin{tabular}{cccccccc}
\hline \multirow{2}{*}{ Sample } & \multicolumn{4}{c}{ Weight/\% } & \multicolumn{3}{c}{ Atomic Ratio } \\
& $\mathbf{K}$ & $\mathbf{N a}$ & $\mathbf{C e}$ & $\mathbf{M n}$ & $\mathbf{K} / \mathbf{M n}$ & $\mathbf{N a} / \mathbf{M n}$ & $\mathbf{C e} / \mathbf{M n}$ \\
\hline $\mathrm{Ce}_{0.01} \mathrm{Mn}-400$ & 7.10 & 1.99 & 1.18 & 49.20 & 0.340 & 0.057 & 0.009 \\
$\mathrm{Ce}_{0.01} \mathrm{Mn}-\mathrm{AT}$ & 1.30 & 0.01 & 1.06 & 52.01 & 0.059 & 0.004 & 0.008 \\
\hline
\end{tabular}

The $\mathrm{N}_{2}$ adsorption/desorption isotherms and the pore size distribution of the $\mathrm{Ce}_{0.01} \mathrm{Mn}-400$ and $\mathrm{Ce}_{0.01} \mathrm{Mn}-\mathrm{AT}$ samples are shown in Figure 2 and the data obtained from these isotherms - the BET surface area $\left(\mathrm{S}_{\mathrm{BET}}\right)$, pore diameter $(\mathrm{Dp})$ and total pore volume (Vp) - are shown in Table 2. The two samples exhibited type IV isotherms, which are given by mesoporous materials. However, the two physisorption hysteresis loops appeared in different shapes. The $\mathrm{Ce}_{0.01} \mathrm{Mn}-400$ sample presented an $\mathrm{H} 3$ loop while $\mathrm{Ce}_{0.01} \mathrm{Mn}-\mathrm{AT}$ presented an $\mathrm{H} 2$ loop. This change in hysteresis loop from $\mathrm{H} 3$ to $\mathrm{H} 2$ can be ascribed to the change in pore shape [29] caused by the acid treatment. Both the surface area and total pore volume were significantly increased after acid treatment. Such modification of textural properties can be explained by the $\mathrm{H}^{+}$exchange during the acid treatment, which can destabilize the layered structure. 


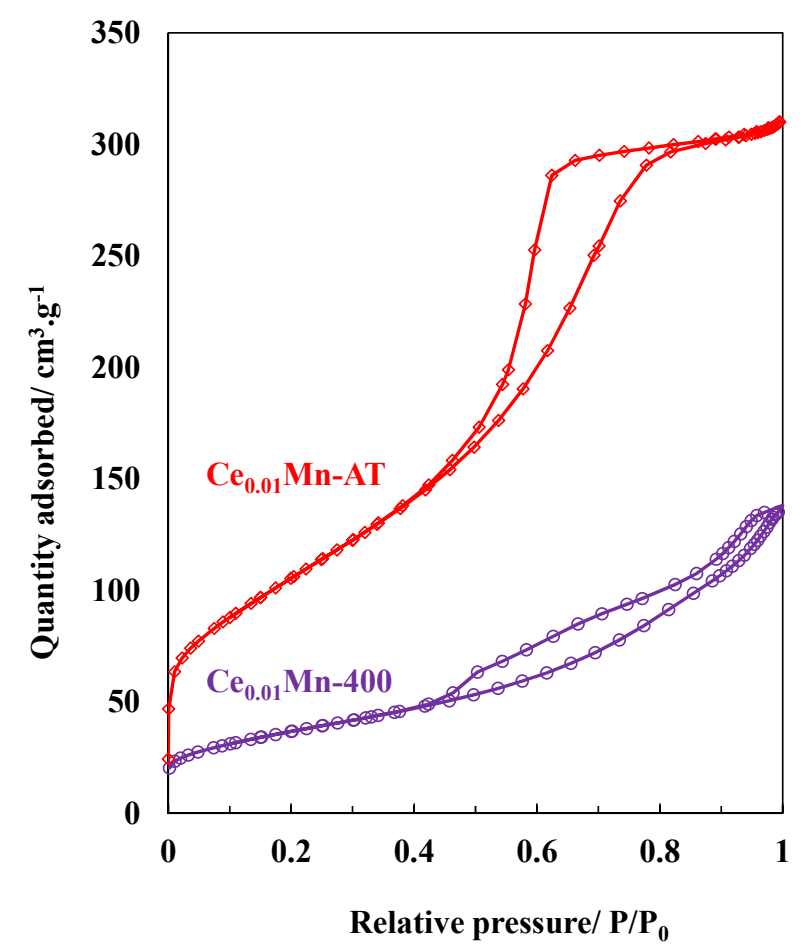

(a)

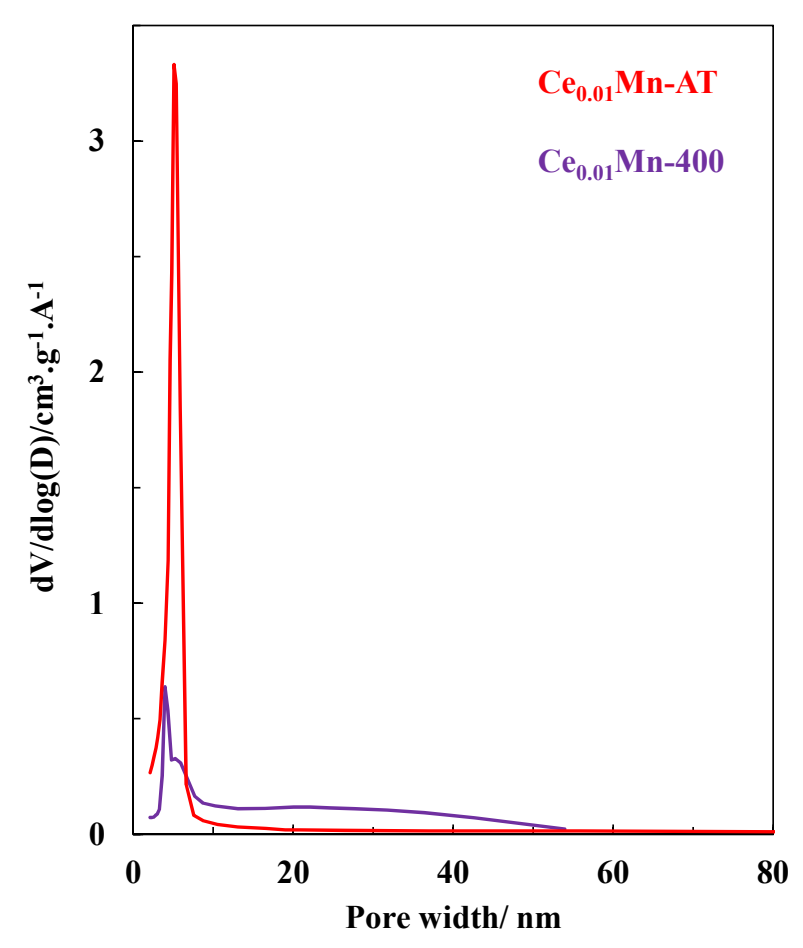

(b)

Figure 2. (a) $\mathrm{N}_{2}$ adsorption and desorption and (b) pore size distribution of $\mathrm{Ce}_{0.01} \mathrm{Mn}-400$ and $\mathrm{Ce}_{0.01} \mathrm{Mn}-\mathrm{AT}$ samples.

Table 2. Textural properties of the $\mathrm{Ce}_{0.01} \mathrm{Mn}-400$ and $\mathrm{Ce}_{0.01} \mathrm{Mn}-\mathrm{AT}$ samples.

\begin{tabular}{cccc}
\hline Sample & $\mathrm{S}_{\text {BET }} / \mathbf{m}^{2} / \mathbf{g}$ & $\mathrm{Dp}_{\text {max }} / \mathbf{n m}$ & $\mathbf{V p}_{\text {tot }} / \mathbf{c m}^{3} / \mathbf{g}$ \\
\hline $\mathrm{Ce}_{0.01} \mathrm{Mn}-400$ & 132 & 4.0 & 0.22 \\
$\mathrm{Ce}_{0.01} \mathrm{Mn}-\mathrm{AT}$ & 385 & 5.3 & 0.37 \\
\hline
\end{tabular}

The change in surface acidity was evaluated using pyridine as an infrared probe molecule for the dried $\mathrm{Ce}_{0.01} \mathrm{Mn}$-and $\mathrm{Ce}_{0.01} \mathrm{Mn}$-AT samples. FTIR spectra of the pyridine region obtained after pyridine adsorption at $150{ }^{\circ} \mathrm{C}$ for the dried $\mathrm{Ce}_{0.01} \mathrm{Mn}$ and $\mathrm{Ce}_{0.01} \mathrm{Mn}-$ AT samples are shown in Figure 3. The interaction of pyridine with dried $\mathrm{Ce}_{0.01} \mathrm{Mn}$ led to a spectrum with large bands. A narrower band can be observed at $1540 \mathrm{~cm}^{-1}$, which can be assigned to the formation of pyridinium ions resulting from pyridine protonation on Brønsted acid sites. The interaction of pyridine with $\mathrm{Ce}_{0.01} \mathrm{Mn}$-AT gave rise to a set of several bands: (i) two bands at 1540 and $1635 \mathrm{~cm}^{-1}$, associated with pyridinium ions resulting from pyridine protonation on Brønsted acid sites; (ii) two bands at 1450 and $1610 \mathrm{~cm}^{-1}$, attributed to pyridine coordinated with Lewis acid sites; and (iii) overlapping bands of pyridine on Lewis and Brønsted acid sites at $1487 \mathrm{~cm}^{-1}$ [22,30-33]. Moreover, the band at $1573 \mathrm{~cm}^{-1}$ can be attributed to the pyridine physisorption (P) [20], while the band at $1471 \mathrm{~cm}^{-1}$ could have resulted from the interaction between the adsorbed pyridine and manganese oxides [34]. $\mathrm{Mn}^{3+}$ and $\mathrm{Mn}^{4+}$ species, as coordinatively unsaturated metal atoms which can accept an electron pair, can be considered as Lewis acid sites, while the hydroxyl groups attached to the metal oxides $(\mathrm{Mn}-\mathrm{OH})$ can be identified as Brønsted acid sites [35]. 


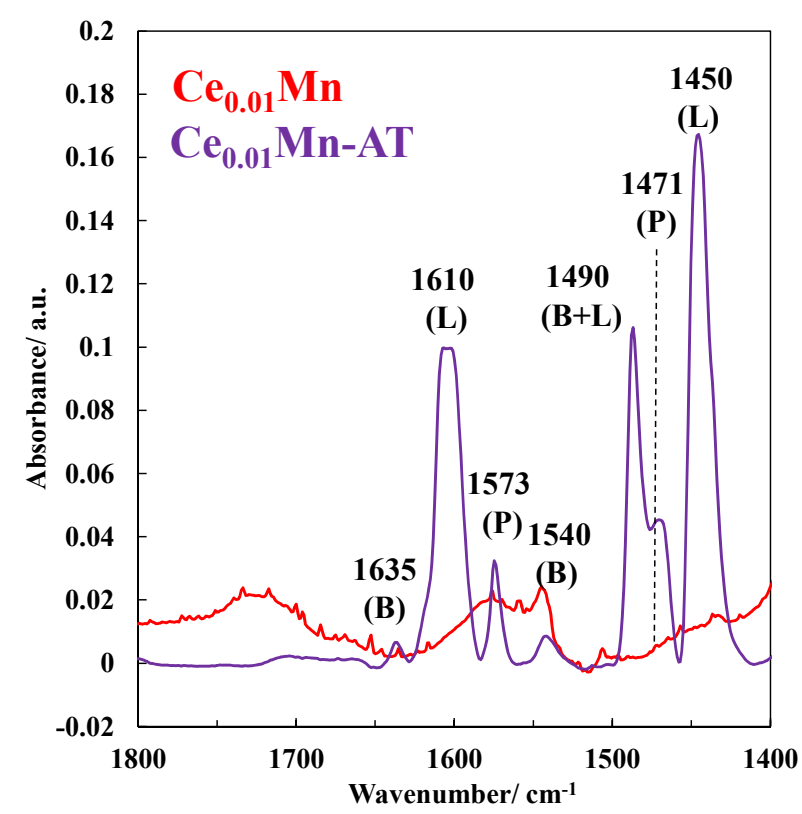

Figure 3. FTIR spectra of the Py region obtained after Py adsorption at $150{ }^{\circ} \mathrm{C}$ for the dried $\mathrm{Ce}_{0.01} \mathrm{Mn}$ and $\mathrm{Ce}_{0.01} \mathrm{Mn}-\mathrm{AT}$ samples.

The surface speciation of manganese species in both samples was assessed by analyzing the $2 \mathrm{p}$ photopeak of $\mathrm{Mn}$. The Mn 2 $\mathrm{p}_{3 / 2}$ signal was decomposed by considering a mixture of $\mathrm{Mn}$ (III) and Mn (IV), as shown in Figure 4 [36]. The obtained $\mathrm{Mn}^{3+} / \mathrm{Mn}^{4+}$ ratio was higher for the acid-treated sample (0.38) compared to the calcined one (0.34). In addition to curve-fitting of the $\mathrm{Mn} \mathrm{2} \mathrm{p}_{3 / 2}$ signal, the Mn 3s photopeak can also provide useful insight into the Mn average oxidation state (Mn AOS) [37,38]. Indeed, the Mn 3s photopeak is split into two signals and the value of the splitting is an indication of the average oxidation state of Mn. The Mn AOS values calculated from the Mn 3s splitting were 3.32 and 3.44 for the $\mathrm{Ce}_{0.01} \mathrm{Mn}-400$ and $\mathrm{Ce}_{0.01} \mathrm{Mn}$-AT samples, respectively. These results agree with the aforementioned $\mathrm{Mn}^{3+} / \mathrm{Mn}^{4+}$ ratio. As expected, the acid treatment generated additional oxygen vacancies to maintain electronic balance, and more $\mathrm{Mn}^{3+}$ species were present at the surface of the $\mathrm{Ce}_{0.01} \mathrm{Mn}$-AT sample $[23,39]$.

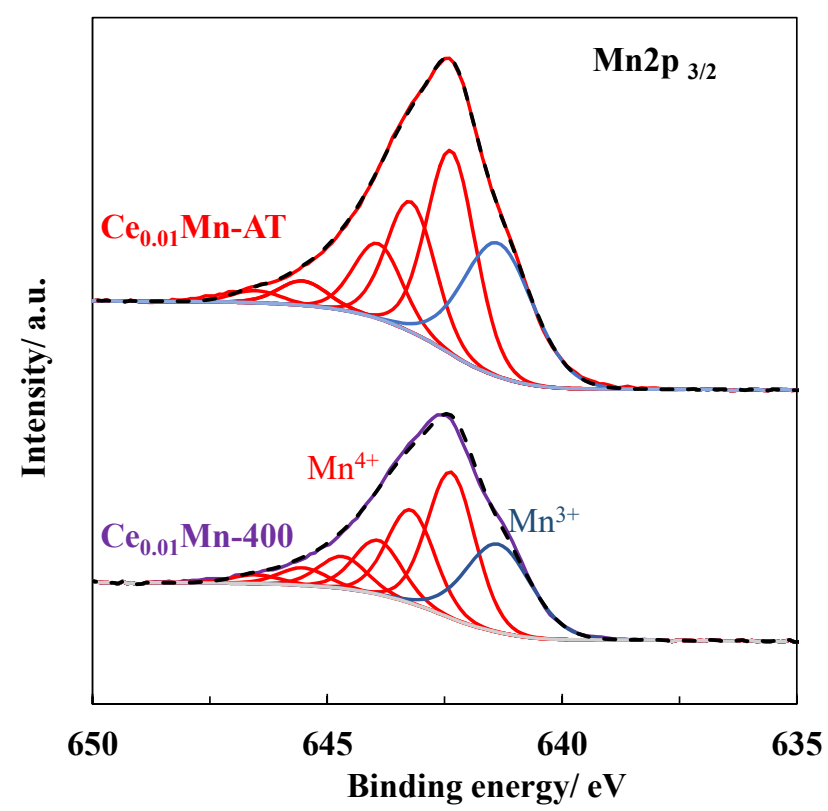

Figure 4. XPS Mn2 $\mathrm{p}_{3 / 2}$ core level decomposition for $\mathrm{Ce}_{0.01} \mathrm{Mn}-400$ and $\mathrm{Ce}_{0.01} \mathrm{Mn}-\mathrm{AT}$ samples. 
It should be noted, however, that it was not possible to assess the proportion of $\mathrm{Ce}^{3+} / \mathrm{Ce}^{4+}$ in the samples due to overlap of the Ce $3 \mathrm{~d}$ and Auger Mn LMN peaks.

2.2. $\mathrm{O}_{3}$ Decomposition in $\mathrm{Ce}_{0.01} \mathrm{Mn}$-400 and $\mathrm{Ce}_{0.01} \mathrm{Mn}$-AT Samples Using Non-Thermal Plasma (NTP) as Ozoner

Figure 5 presents the ozone decomposition at room temperature as a function of time with $\mathrm{Ce}_{0.01} \mathrm{Mn}-400$ and $\mathrm{Ce}_{0.01} \mathrm{Mn}$-AT catalysts. $\mathrm{Ce}_{0.01} \mathrm{Mn}-400$ maintained high ozone conversion $(>97 \%)$ for $140 \mathrm{~min}$ but then showed a gradual decrease in ozone conversion to $73 \%$ after $5 \mathrm{~h}$. Ce $\mathrm{e}_{0.01} \mathrm{Mn}$-AT exhibited different behavior, with a low decrease in ozone conversion after $30 \mathrm{~min}$ of testing from $100 \%$ to $94 \%$ after $120 \mathrm{~min}$. Thereafter, $\mathrm{Ce}_{0.01} \mathrm{Mn}-\mathrm{AT}$ was able to maintain this high conversion over time. It has been reported previously that oxygen vacancies play a key role in ozone decomposition in manganese oxides. Therefore, the better catalytic performance of $\mathrm{Ce}_{0.01} \mathrm{Mn}$-AT compared to that of $\mathrm{Ce}_{0.01} \mathrm{Mn}-400$ was consistent with its more abundant oxygen vacancies, which were in accordance with the larger amount of surface $\mathrm{Mn}^{3+}$ species (XPS). This result confirms the important role of oxygen vacancies in catalytic ozone decomposition, as reported in the literature [40-43]. In addition, the larger specific surface area of $\mathrm{Ce}_{0.01} \mathrm{Mn}$-AT may contribute to a wider surface exposure of oxygen vacancies. This could explain the high ozone conversion maintained in the presence of $\mathrm{Ce}_{0.01} \mathrm{Mn}$-AT alongside the avoidance of the saturation of the oxygen vacancies sites, which was probably at the origin of the deactivation observed in the presence of $\mathrm{Ce}_{0.01} \mathrm{Mn}-400[44,45]$.

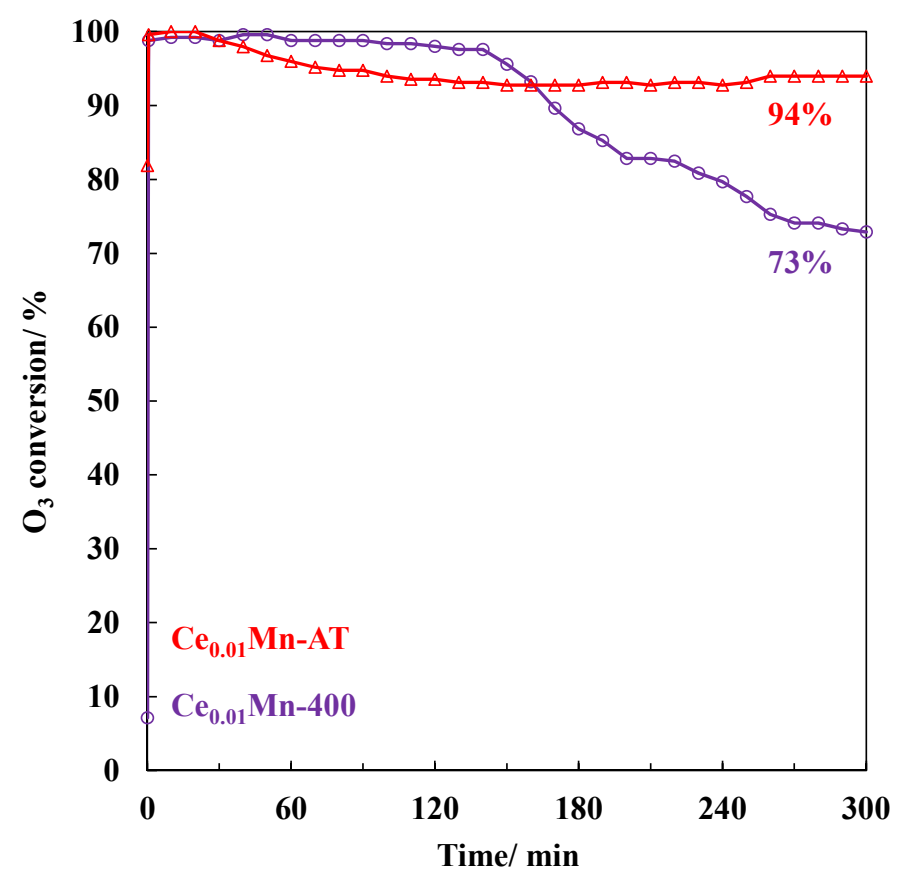

Figure 5. Ozone conversion in $\mathrm{Ce}_{0.01} \mathrm{Mn}-400$ and $\mathrm{Ce}_{0.01} \mathrm{Mn}-\mathrm{AT}\left(\left[\mathrm{O}_{3}\right]=300 \mathrm{ppmv}, \mathrm{GHSV}=1200 \mathrm{~L} /\left(\mathrm{g}_{\text {cata }} \cdot \mathrm{h}\right)\right.$; $\mathrm{RH}=0.7 \%)$.

\subsection{TCE Abatement by Non-Thermal Plasma (NTP)}

The initial TCE concentration ([TCE $]_{0}$ ) was set at 150 ppmv based on the $\mathrm{O}_{3}$ production through the plasma reactor. Indeed, without TCE and $\mathrm{H}_{2} \mathrm{O}$ in the feed, the ozone concentration at the exit of the plasma reactor was $600 \mathrm{ppmv}$. Thus, the $\left[\mathrm{O}_{3}\right] /[\mathrm{TCE}]_{0}$ ratio equal to the stoichiometric ratio for $4 \mathrm{O}_{3}$ molecules, considering the total transformation of the initial amount of $\mathrm{C}$ into $\mathrm{CO}_{2}$, can be deduced as follows:

$$
\mathrm{C}_{2} \mathrm{Cl}_{3} \mathrm{H}+4 \mathrm{O}_{3}=2 \mathrm{CO}_{2}+4 \mathrm{O}_{2}+\mathrm{HCl}+\mathrm{Cl}_{2}
$$


Regardless of the water content in the feed, $\mathrm{RH}=0.7 \%$ or $\mathrm{RH}=15 \%$, TCE molecules were not fully degraded in the NTP process, since the TCE conversion reached $85 \%$ and $59 \%$, respectively. Moreover, $\mathrm{O}_{3}$ molecules were still present at the outlet of the plasma reactor at 315 and 190 ppmv. The fact that the lowest $\mathrm{O}_{3}$ concentration was found at the outlet of the plasma reactor for the NTP-RH15\% test, despite also having the lowest obtained TCE conversion, can be ascribed to the reaction of $\mathrm{OH}$ radicals coming from the $\mathrm{H}_{2} \mathrm{O}$ decomposition in the plasma reactor [46,47], as these radicals can react with $\mathrm{O}_{3}$ in the plasma [48-51]. Additionally, the COx yields were $46 \%$ and $34 \%$ for the NTP TCE abatement with RHs of $0.7 \%$ and $15 \%$, respectively (Figure 6). Interestingly, in comparison with results obtained with the same plasma discharge and plasma reactor (COx yield of $15 \%$ in humid air $(\mathrm{RH}=15 \%)$ for ED of $\left.120 \mathrm{~J} \cdot \mathrm{L}^{-1}\right)$, the mineralization of TCE was here much higher, probably as a result of the optimized $\left[\mathrm{O}_{3}\right] /[\mathrm{TCE}]_{0}$ ratio of 4 , instead of less than 1 as used in previous studies [12,13,52,53].

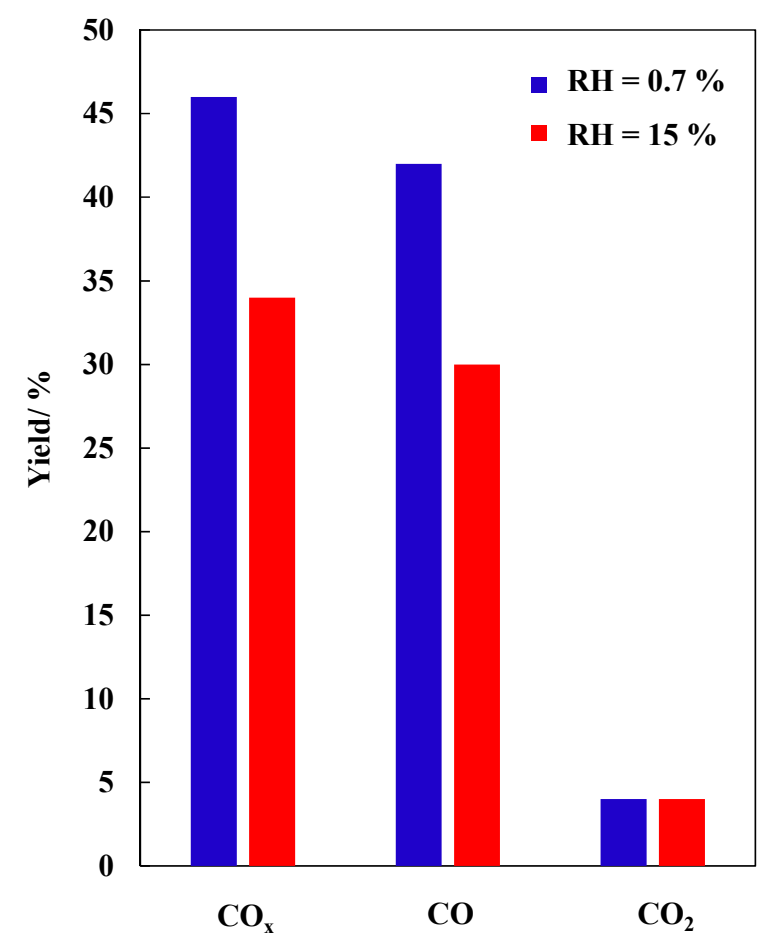

Figure 6. $\mathrm{CO}_{\mathrm{x}}, \mathrm{CO}$ and $\mathrm{CO}_{2}$ yields obtained in NTP TCE abatement with $\mathrm{RH}$ of $0.7 \%$ and $15 \%$ $\left(\mathrm{ED}=150 \mathrm{~J} / \mathrm{L} ; \mathrm{Q}=1 \mathrm{~L} / \mathrm{min} ;[\mathrm{TCE}]_{0}=150 \mathrm{ppmv}\right)$.

The FTIR spectra of the inlet TCE and outlet stream after NTP TCE abatement, with $0.7 \%$ and $15 \%$ as the relative humidity, are presented in Figure 7 . The FTIR spectra for the inlet TCE showed the characteristic bands of TCE. The characteristics bands for TCE at 945 and $865 \mathrm{~cm}^{-1}$ were still present but their relative intensities were higher in humid air, in accordance with the lowest TCE conversion discussed above. Furthermore, (oxi-)chlorinated by-products, such as dichloroacetchloride (DCAC; IR bands at 740, 989, 1076, 1055 (overlap with $\mathrm{O}_{3}$ ) and $1773 \mathrm{~cm}^{-1}$ ), phosgene (PG; IR bands at 852 (overlap with TCE) and $1827 \mathrm{~cm}^{-1}$ ) and trichloroacetaldehyde (TCAD; IR band at $1760 \mathrm{~cm}^{-1}$ ), were also detected in line with the incomplete gaseous oxidation of TCE. The detection and possible reaction schemes of formation of such (oxi-)chlorinated oxidation by-products have already been discussed elsewhere [46-48]. With almost no water in the feed $(\mathrm{RH}=0.7 \%)$, TCE molecules react with $\mathrm{ClO}$ radicals to produce DCAC, then DCAC molecules further decompose from the attack of $\mathrm{Cl}$ radicals to produce $\mathrm{CCl}_{4}, \mathrm{CHCl}_{3}$ and $\mathrm{COCl}_{2}$ molecules [46,53]. However, with $\mathrm{RH}$ of $15 \%, \mathrm{ClO}$ radicals will certainly be quenched by $\mathrm{OH}$ radicals (coming from $\mathrm{H}_{2} \mathrm{O}$ ), leading to a lower amount of DCAC (Figure 7). 


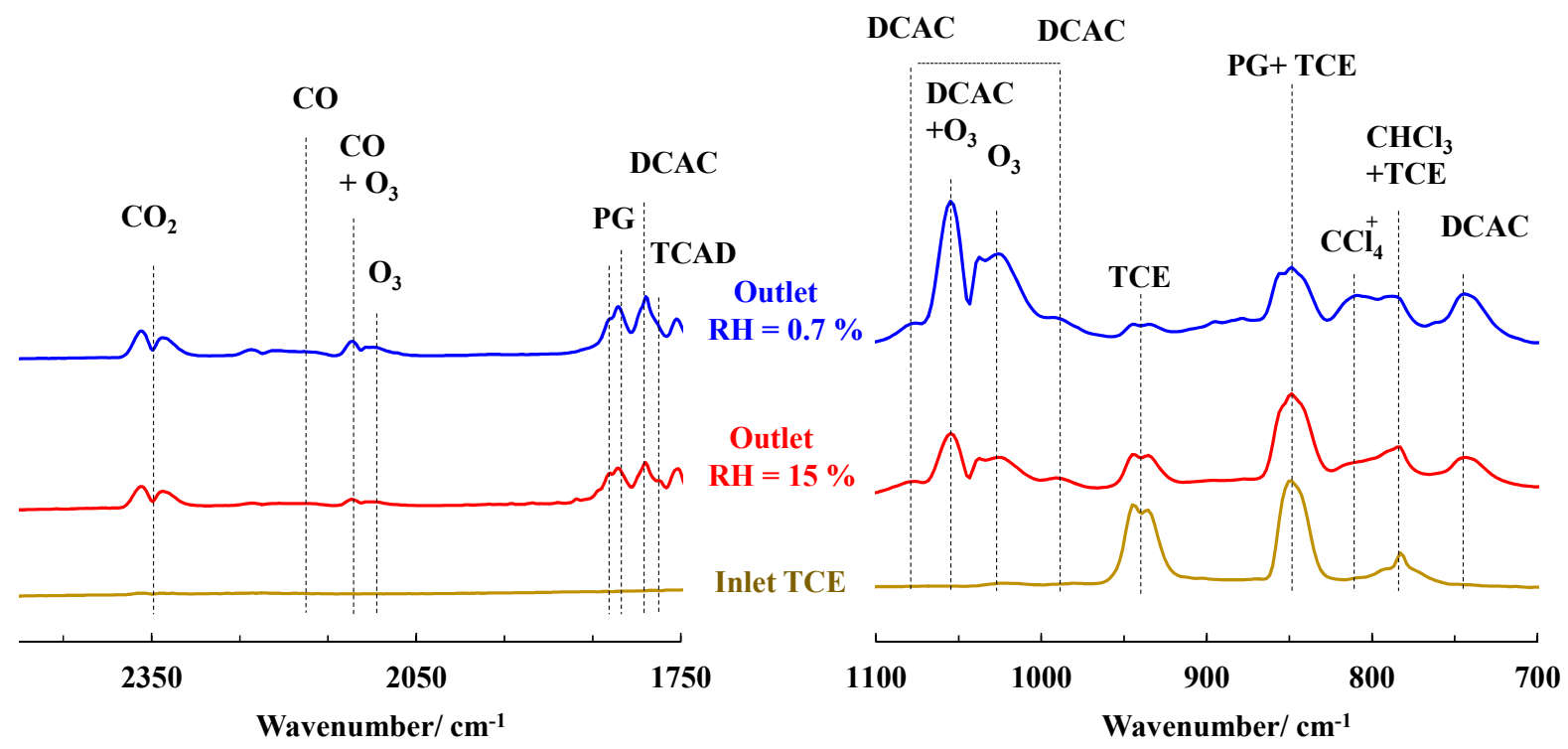

Figure 7. FT-IR spectra for the ranges $2500-1700 \mathrm{~cm}^{-1}$ and $1110-700 \mathrm{~cm}^{-1}$ of the outlet stream after NTP with $0.7 \% 15 \%$ as relative humidity $(\mathrm{ED}=150 \mathrm{~J} / \mathrm{L}, \mathrm{Q}=1 \mathrm{~L} / \mathrm{min})$. PG: phosgene; DCAC: dichloroacetylchloride; TCAD: trichloroacetaldehyde.

\subsection{TCE Abatement by Non-Thermal Plasma (NTP)}

In the PPC configuration with $\mathrm{RH}=0.7 \%$, TCE was fully converted regardless of the catalysts $\left(\mathrm{Ce}_{0.01} \mathrm{Mn}-\mathrm{AT}\right.$ and $\left.\mathrm{Ce}_{0.01} \mathrm{Mn}-400\right)$ used. Figure 8 shows the $\mathrm{CO}_{\mathrm{x}}$ and $\mathrm{CO}_{2}$ yields with the two catalysts as a function of time. Compared with NTP, the $\mathrm{CO}_{\mathrm{x}}$ yield increased and the $\mathrm{CO}_{2}$ yield especially significantly improved from 4 to $58 \%$ at $\mathrm{t}=0$. Of the two PPC configurations, the one with $\mathrm{Ce}_{0.01} \mathrm{Mn}$-AT downstream of the NTP outperformed the one with $\mathrm{Ce}_{0.01} \mathrm{Mn}-400$ for the $5 \mathrm{~h}$ test. For both configurations, $\mathrm{CO}_{\mathrm{x}}$ and $\mathrm{CO}_{2}$ yields decreased over the time of the reaction. However, for $\mathrm{Ce}_{0.01} \mathrm{Mn}-400$ the decay was more pronounced during the first $30 \mathrm{~min}$. After $120 \mathrm{~min}$ the catalysts seemed to reach a steady state, as the $\mathrm{CO}_{\mathrm{x}}$ and $\mathrm{CO}_{2}$ yield values were rather constant (Figure 8).

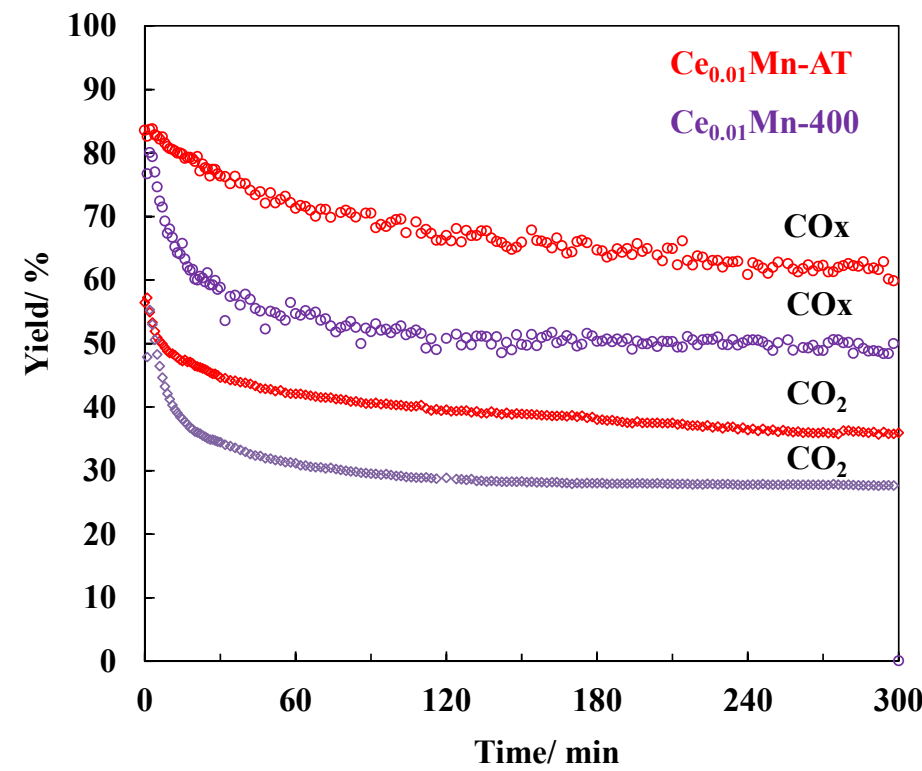

Figure 8. $\mathrm{CO}_{x}$ and $\mathrm{CO}_{2}$ yields obtained for TCE abatement $(\mathrm{RH}=0.7 \%)$ in the PPC configuration with $\mathrm{Ce}_{00.1} \mathrm{Mn}-400$ and $\mathrm{Ce}_{0.01} \mathrm{Mn}-\mathrm{AT}$ as catalysts.

Figures 9 and 10 present the FTIR spectra recorded between 700 and $1110 \mathrm{~cm}^{-1}$ and 1700 and $1800 \mathrm{~cm}^{-1}$ for the inlet TCE and the outlet gaseous stream as a function of time 
after post-plasma treatment using $\mathrm{Ce}_{0.01} \mathrm{Mn}-400$ and $\mathrm{Ce}_{0.01} \mathrm{Mn}-\mathrm{AT}$ with $\mathrm{RH}=0.7 \%$. In the PPC configurations, as compared with NTP, the band at $945 \mathrm{~cm}^{-1}$, corresponding to TCE, was not observed, while the intensity of the bands corresponding to $\mathrm{CO}_{2}$ vibration increased for both catalysts. Similarly, the ozone band disappeared. Interestingly, the characteristic bands of DCAC and TCAC decreased in intensity when $\mathrm{Ce}_{0.01} \mathrm{Mn}-400$ was used as the catalyst and even disappeared with the $\mathrm{Ce}_{0.01} \mathrm{Mn}$-AT catalyst. Such results could have been related to the efficient $\mathrm{O}_{3}$ activation of the catalysts, allowing the decomposition of the DCAC and TCAC by-products. Based on the relative intensity of the PG band, it seems that after one hour the PG amount was almost the same, irrespective of the catalyst. It is noticeable that new bands emerged corresponding to $\mathrm{C}-\mathrm{Cl}$ bond vibrations relative to $\mathrm{CHCl}_{3}$ and $\mathrm{CCl}_{4}$, located at wavenumbers of $774 \mathrm{~cm}^{-1}$ and $794 \mathrm{~cm}^{-1}$, respectively. These $\mathrm{C} 1$ chlorinated formations can be explained by the reaction of $\mathrm{CHCl}_{2}$ and $\mathrm{CCl}_{3}$ radicals, resulting mainly from the easy cleavage of the carbon-carbon bond of DCAC with adsorbed chlorine.
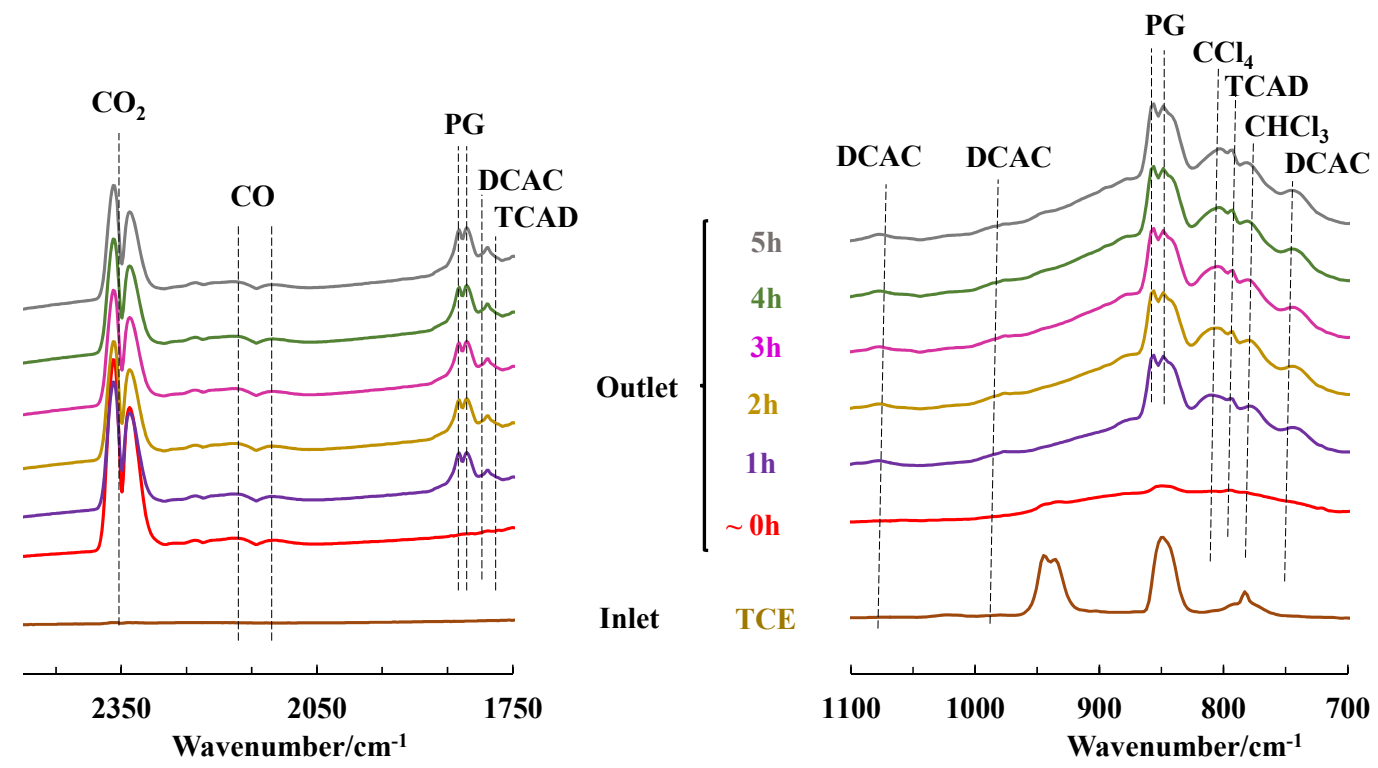

Figure 9. FT-IR spectra of the inlet TCE and outlet gaseous stream after the PPC process $(\mathrm{RH}=0.7 \%)$ as a function of time with $\mathrm{Ce}_{0.01} \mathrm{Mn}-400$ as the catalyst. PG: phosgene; DCAC: dichloroacetylchloride; TCAD: trichloroacetaldehyde.
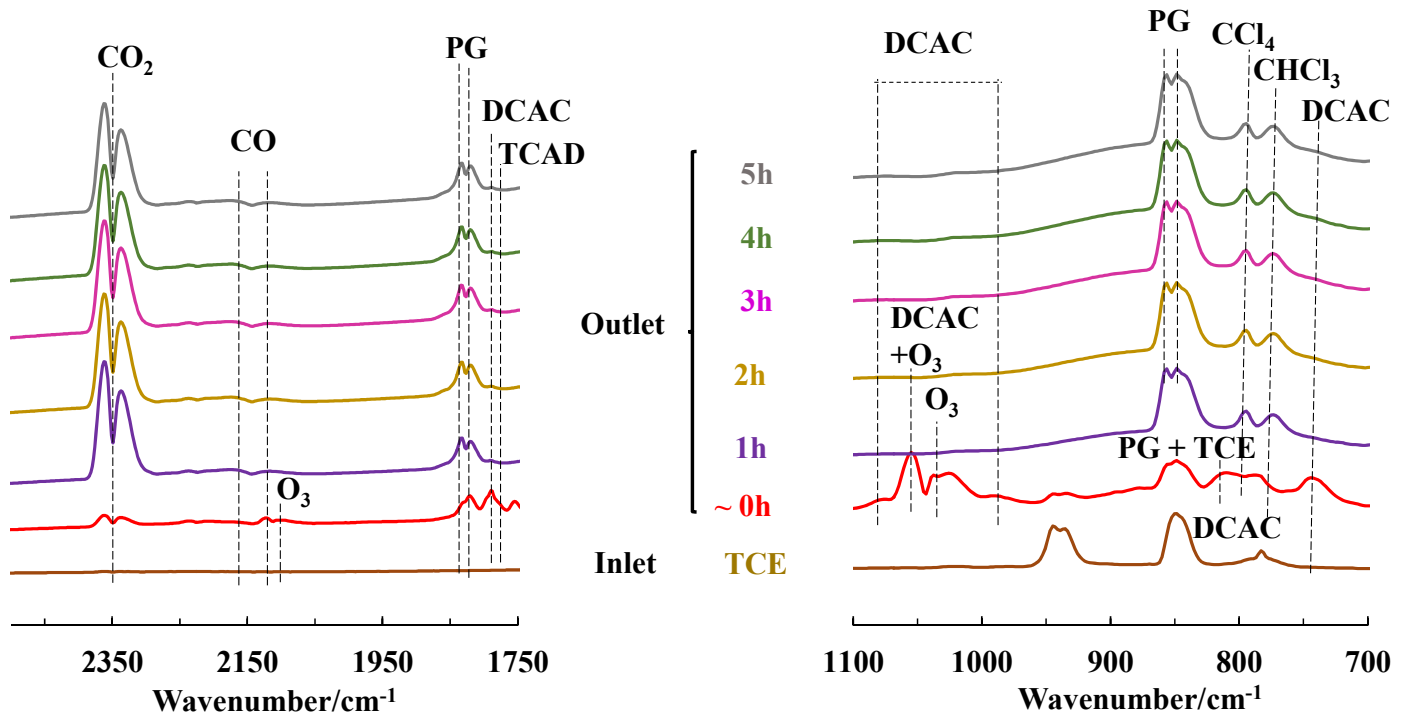

Figure 10. FT-IR spectra of the inlet TCE and outlet gaseous stream after the PPC process $(\mathrm{RH}=0.7 \%)$ as a function of time with $\mathrm{Ce}_{0.01} \mathrm{Mn}-\mathrm{AT}$ as the catalyst. PG: phosgene; DCAC: dichloroacetylchloride; TCAD: trichloroacetaldehyde. 


\subsection{TCE Abatement in Post-Plasma Catalysis (PPC) Configuration-RH $=15 \%$}

The effect of relative humidity on the PPC process for TCE decomposition was studied in the presence of $\mathrm{Ce}_{0.01} \mathrm{Mn}-\mathrm{AT}$ as the best catalyst. Figure 11 shows the $\mathrm{CO}_{\mathrm{x}}$ and $\mathrm{CO}_{2}$ yields obtained as a function of time in humid air $(\mathrm{RH}=15 \%)$. In comparison with the $\mathrm{RH}=0.7 \%$ condition, the yields were lower but rather stable during the $5 \mathrm{~h}$ of the experiment.

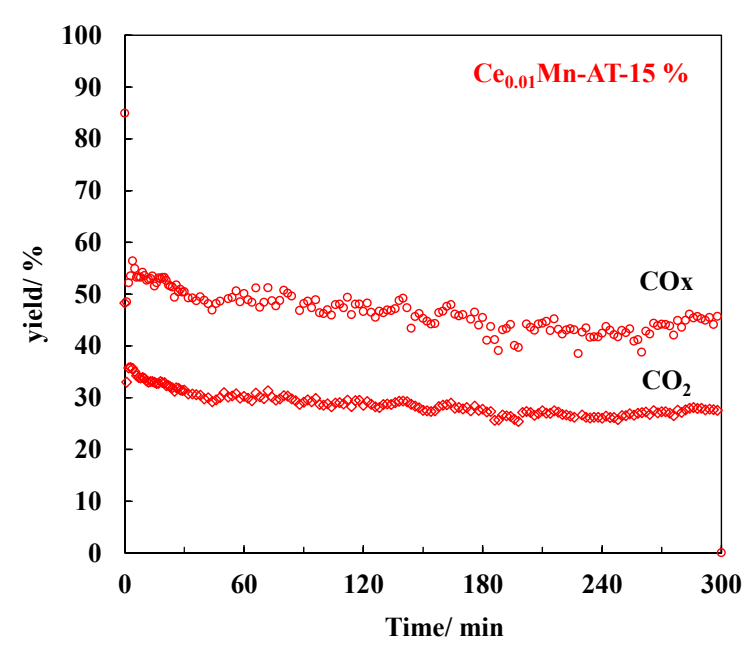

Figure 11. $\mathrm{CO}_{\mathrm{x}}$ and $\mathrm{CO}_{2}$ yields obtained for TCE abatement $(\mathrm{RH}=15 \%)$ in the PPC configuration with $\mathrm{Ce}_{0.01} \mathrm{Mn}-\mathrm{AT}$ as the catalyst.

Figure 12 presents the FT-IR spectra of the inlet TCE and outlet gaseous stream after the PPC process $(\mathrm{RH}=15 \%)$ with $\mathrm{Ce}_{0.01} \mathrm{Mn}-\mathrm{AT}$ as catalyst as a function of time. As previously observed with $\mathrm{RH}=0.7 \%$, neither the bands for TCE nor the ozone bands were observed after the PPC process. The DCAC and TCAD bands were observed, in contrast to what we observed in the PPC process with $\mathrm{RH}=0.7 \%$. However, it is usually reported that (i) the DCAC formation comes from the reaction of TCE with $\mathrm{ClO}$ radicals and (ii) in the presence of water, DCAC formation is suppressed because of the quenching of $\mathrm{ClO}$ radicals by $\mathrm{OH}$ radicals according to the following reaction: $\mathrm{ClO}+\mathrm{OH} \rightarrow \mathrm{HCl}+\mathrm{O}_{2}$. This discrepancy could be explained by the presence of ozone in higher quantities in our experimental conditions in comparison with those found in the literature. In our experimental conditions, $\mathrm{OH}$ radicals could react with $\mathrm{O}_{3}$ in sufficient quantities, instead of $\mathrm{ClO}$ radicals. This result could also explain the lowest $\mathrm{COx}$ yield value, owing to $\mathrm{O}_{3}$ consumption by $\mathrm{OH}$ radicals.
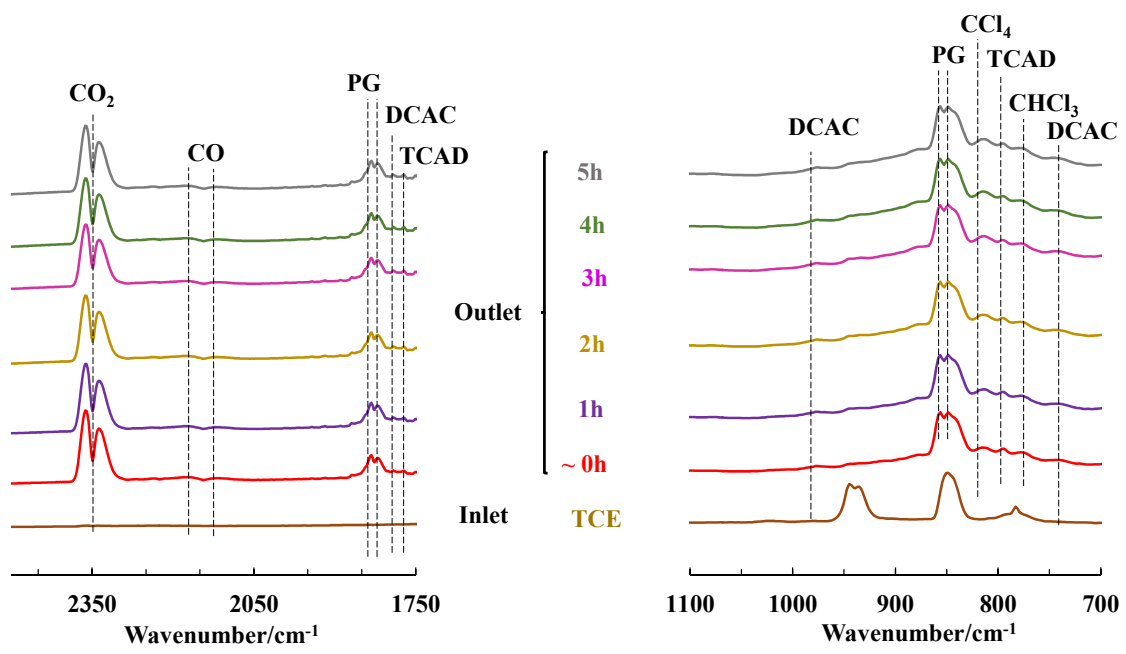

Figure 12. FT-IR spectra of the inlet TCE and outlet gaseous stream after the PPC process $(\mathrm{RH}=15 \%)$ with $\mathrm{Ce}_{0.01} \mathrm{Mn}-\mathrm{AT}$ as the catalyst as a function of time. PG: phosgene; DCAC: dichloroacetylchloride; TCAD: trichloroacetaldehyde. 


\subsection{XPS Characterization of the Used Catalysts after the PPC Process}

After the PPC process, a slight oxidation of manganese species was observed at the surface in both catalysts. Indeed, the $\mathrm{Mn}^{3+} / \mathrm{Mn}^{4+}$ decreased (Figure 13a), which was in agreement with the increase of Mn AOS calculated from Mn 3s splitting (Table 3). All catalysts also presented a surface Ce enrichment in Mn after the PPC process. After the reaction, the chlorine element was detected on the surfaces of both catalysts (Table 3). This can be explained by the incomplete degradation of TCE during the PPC process. The $\mathrm{Cl}$ $2 p$ core level envelope can be simulated by considering two types of chlorine (Figure 13b). The $\mathrm{Cl} 2 \mathrm{p}_{3 / 2}$ photopeak at $198.5 \pm 0.2 \mathrm{eV}$ can be attributed to metal $(\mathrm{M})$ chloride, with $\mathrm{M}=\mathrm{Ce}$ and/or Mn [49,52], while the $\mathrm{Cl} 2 \mathrm{p}_{3 / 2}$ photopeak at $200.6 \pm 0.2 \mathrm{eV}$ can be ascribed to (oxi-)chlorinated organic species such as $\mathrm{CH}_{\mathrm{x}} \mathrm{Cl}_{\mathrm{y}}\left(\mathrm{O}_{\mathrm{z}}\right)$ [49,52]. The organic chlorine to mineral chlorine ratio $\left(\mathrm{Cl}_{\mathrm{org}} / \mathrm{Cl}_{\min }\right)$ was calculated for the tested catalysts. The best catalyst for TCE degradation (Ce $\left.\mathrm{C}_{0.01} \mathrm{Mn}-\mathrm{AT}\right)$ presented a lower $\mathrm{Cl}_{\text {org }} / \mathrm{Cl}_{\min }$ ratio (0.14) in comparison with the ratio obtained for $\mathrm{Ce}_{0.01} \mathrm{Mn}-400(0.42)$, suggesting that the formation of (oxi-)chlorinated organic species at the surface is detrimental to the catalytic performance. This assumption is reinforced by comparing the ratios obtained for the catalysts tested in different $\mathrm{RH}$ conditions. Indeed, with $\mathrm{RH}=15 \%$, the activity of $\mathrm{Ce}_{0.01} \mathrm{Mn}$-AT was lower and the $\mathrm{Cl}_{\text {org }} / \mathrm{Cl}_{\min }$ ratio was higher (0.35).

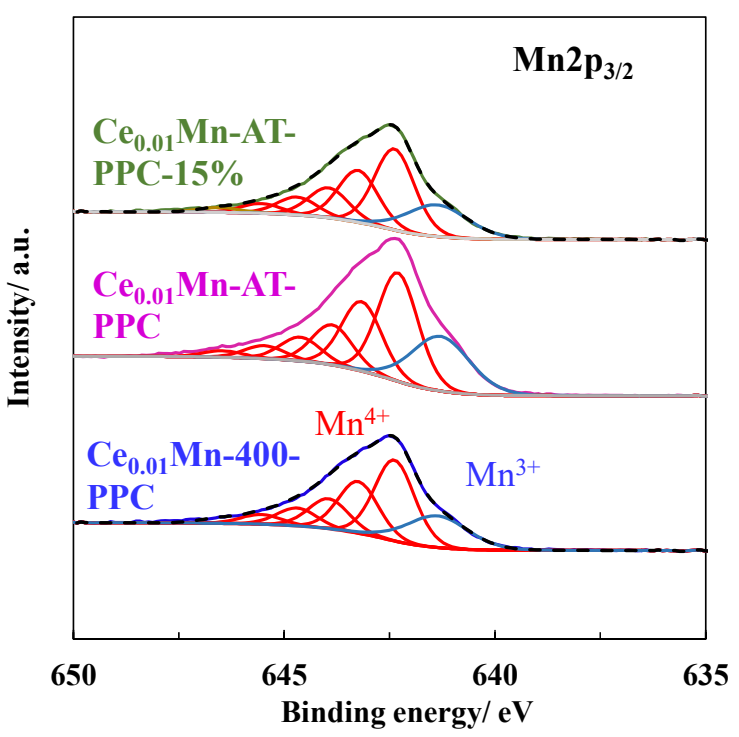

(a)

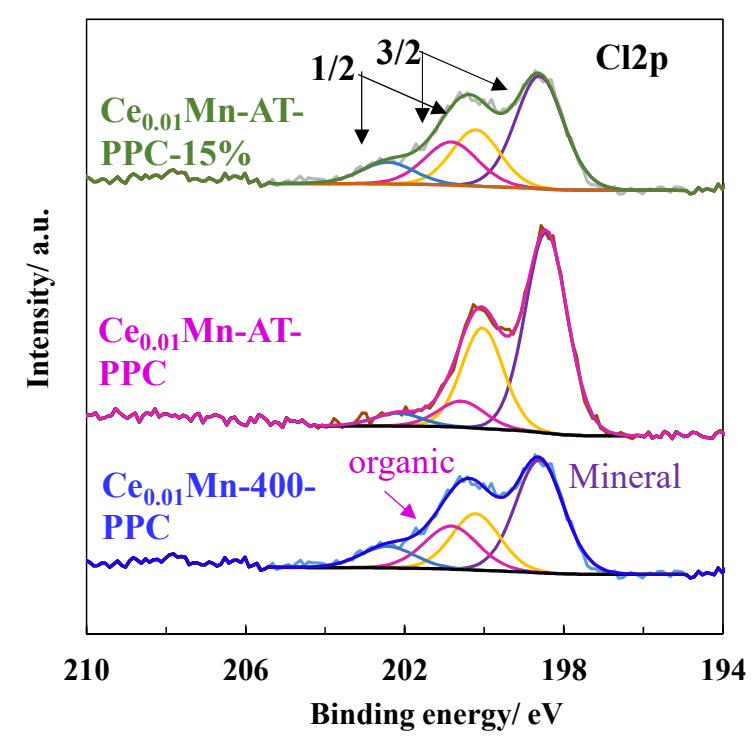

(b)

Figure 13. Decomposition of XPS (a) Mn2 $\mathrm{p}_{3 / 2}$ and (b) $\mathrm{Cl} 2 \mathrm{p}$ core levels after the PPC process.

Table 3. Semi-quantitative XPS analysis for used (PPC) catalysts.

\begin{tabular}{cccccccc}
\hline Catalyst & O/Mn & K/Mn & $\mathbf{N a} / \mathbf{M n}$ & $\mathbf{C e} / \mathbf{M n}$ & $\mathbf{C l} / \mathbf{M n}$ & $\mathbf{M n}^{3+} / \mathbf{M n}^{4+}$ & $\mathbf{M n}$ AOS from Mn 3s Splitting \\
\hline $\mathrm{Ce}_{0.01} \mathrm{Mn}-400$ & 2.07 & 0.18 & 0.05 & 0.015 & & 0.34 & 3.44 \\
$\mathrm{Ce}_{0.01} \mathrm{Mn}-400-\mathrm{PPC}$ & 2.34 & 0.26 & 0.05 & 0.024 & 0.18 & 0.21 & 3.56 \\
$\mathrm{Ce}_{0.01} \mathrm{Mn}-\mathrm{AT}$ & 1.97 & 0.06 & - & 0.018 & & 0.38 & 3.32 \\
$\mathrm{Ce}_{0.01} \mathrm{Mn}-\mathrm{AT}-\mathrm{PPC}$ & 1.91 & 0.04 & - & 0.028 & 0.16 & 0.29 & 3.42 \\
$\mathrm{Ce}_{0.01} \mathrm{Mn}-\mathrm{AT}-\mathrm{PPC}-15 \%$ & 1.81 & 0.04 & - & 0.025 & 0.22 & 0.28 & 3.41 \\
\hline
\end{tabular}

\section{Materials and Methods}

\subsection{Catalyst Preparation}

Ce-doped birnessite with a ratio of $\mathrm{Ce} / \mathrm{Mn}=0.01$ was prepared following a redox method. Typically, $4.0 \mathrm{~g}$ ( $25.3 \mathrm{mmol})$ of $\mathrm{KMnO}_{4}$ (Fluka, $\geq 99 \%$, Strasbourg, France) was dissolved into $400 \mathrm{~mL}$ of distilled water under stirring (350 rpm). $\mathrm{Ce}\left(\mathrm{NO}_{3}\right)_{3} \cdot 6 \mathrm{H}_{2} \mathrm{O}$ (Alfa Aesar; $\geq 99.5 \%$, Kandel, Germany) was dissolved concomitantly with $\mathrm{KMnO}_{4}$ and $4 \mathrm{~mL}$ 
(22.54 mmol) of $\mathrm{NaC}_{3} \mathrm{H}_{5} \mathrm{O}_{3}(50 \% \mathrm{w} / \mathrm{w})$ (Fisher Chemical, solution 60\% $w / w$, Stasbourg, France) was added dropwise to the aqueous $\mathrm{KMnO}_{4}$ solution. The resulting brown suspension was stirred for $2 \mathrm{~h}$. After centrifugation (4000 rpm for $20 \mathrm{~min}$ ), the collected brown precipitate was washed two times $(25 \mathrm{~mL}$ of distilled water each time) and finally dried in an oven at $40{ }^{\circ} \mathrm{C}$ for $48 \mathrm{~h}$ to give a black powder. The dried sample was then calcined at $400{ }^{\circ} \mathrm{C}$ for $5 \mathrm{~h}$ in flowing dry air $\left(1.0 \mathrm{~g} ; 2 \mathrm{~L} / \mathrm{h} ; 2{ }^{\circ} \mathrm{C} / \mathrm{min}\right)$ and labeled as $\mathrm{Ce}_{0.01} \mathrm{Mn}-400$. The dried sample was also treated with $0.2 \mathrm{M} \mathrm{HNO}_{3}$ solution (VWR $68 \%$ ), with a ratio $\mathrm{m}_{\text {catalyst }}(\mathrm{g}) / \mathrm{V}_{\mathrm{HNO} 3}(\mathrm{~mL})=1 / 20$, for $6 \mathrm{~h}$ at $50{ }^{\circ} \mathrm{C}$ under vigorous stirring $(500 \mathrm{rpm})$. Then, the black suspension was filtered and washed continuously with distilled water until the $\mathrm{pH}$ of the eluate reached $\sim 7.0$. After washing, the resulting black solid was dried at $105^{\circ} \mathrm{C}$ for $18 \mathrm{~h}$ and the sample was labeled as $\mathrm{Ce}_{0.01} \mathrm{Mn}-\mathrm{AT}$.

\subsection{Catalyst Characterization}

X-ray diffraction (XRD) patterns were collected on a D8 Advanced Bruker AXS diffractometer equipped with a $\mathrm{Cu} \mathrm{K} \mathrm{K}_{\alpha 1}$ monochromatic radiation source $(\lambda=1.5418 \AA)$ and Lynxeye super speed detector, with the power levels set at $40 \mathrm{kV}$ and $40 \mathrm{~mA}$. The X-ray diffraction patterns were recorded within the range $5-80^{\circ}$ with a $0.02^{\circ}$ step size in $2 \theta$ and a step time of $1 \mathrm{~s}$.

The elemental analysis was performed with an inductively coupled plasma-Optic emission spectroscope 720-ES ICP-OES. The sample preparation was undertaken by dissolving $10 \mathrm{mg}$ of dried and ground catalyst samples in concentrated aqua regia solution. The sample solution was heated up to $110^{\circ} \mathrm{C}$ in a Vulcan autodigester for $2 \mathrm{~h}$. Then, it was diluted to $20 \mathrm{~mL}$ by ultrapure water before analysis by the ICP-OES. Metal in sample, allowing the estimation of the weight, was undertaken for the analysis-certificated standard solution.

$\mathrm{N}_{2}$ physisorption isotherms were recorded at $-196{ }^{\circ} \mathrm{C}$ using a TriStar II 3020 gas sorption analyzer from Micromeretics. Prior to analysis, the samples were heated at $100{ }^{\circ} \mathrm{C}$ for $4 \mathrm{~h}$ in a dynamic vacuum. The Brunauer-Emmett-Teller (BET) method was used to calculate the specific surface areas. The total pore volume $V_{p}$ was determined at $P / P_{0}=0.99$. The Barret-Joyner-Halenda (BJH) equation was used to estimate the pore size distributions (PSDs) for the desorption branch.

Pyridine adsorption measurements followed by Fourier-transform infrared spectroscopy (FTIR-pyridine) were undertaken with a Thermo Nicolet 460 protege instrument equipped with a CSi beam splitter and an $\mathrm{MCT}$ detector with a $2 \mathrm{~cm}^{-1}$ resolution. A total of 256 scans were collected over the spectral range extending from 4000 to $400 \mathrm{~cm}^{-1}$. The samples were ground in an agate mortar and pressed into the form of self-supporting wafers $\left(1 \mathrm{ton} / \mathrm{cm}^{2}, 2.01 \mathrm{~cm}^{2}\right)$, then placed in a quartz sample holder and afterwards in a quartz cell equipped with $\mathrm{KBr}$ windows. The sample was first activated at $105^{\circ} \mathrm{C}$ in a high vacuum. Then, the pyridine adsorption occurred at $105{ }^{\circ} \mathrm{C}$. After reaching the equilibrium, the excess of pyridine was evacuated in a vacuum at $105{ }^{\circ} \mathrm{C}$ over $30 \mathrm{~min}$. Then, the spectrum acquisition was performed. All recorded spectra were recalculated to a normalized wafer of $10 \mathrm{mg}$ and then the FTIR spectrum of the activated surface was subtracted from the pyridine-adsorbed one.

X-ray photoelectron spectroscopy (XPS) experiments were performed using an AXIS Ultra DLD Kratos spectrometer equipped with a monochromatic aluminum source (Al $\mathrm{K}_{\alpha}=1486.7 \mathrm{eV}$ ) and charge compensation gun. The binding energies (BEs) were referenced from adventitious $C 1 \mathrm{~s}$ at $284.8 \mathrm{eV}$. High resolution spectra were collected with a constant pass energy (40 eV). Quantification and spectral decomposition were processed using CasaXPS software. Quantification was performed based on Mn 2p, Ce 4d, K 2p, O 1s, Na 1 s and C 1s. The Ce $4 \mathrm{~d}$ core-level was considered for quantification instead of Ce $3 \mathrm{~d}$ due to the Ce 3d/Auger Mn LMM peak overlap. 


\subsection{Ozone Decomposition Using Non-Thermal Plasma (NTP)}

Figure 14 presents the schematic diagram of the experimental setup, which consisted of three main parts: the gas analysis system, the reactor system (NTP reactor and catalyst reactor) and the gas analysis system. A total of $300 \mathrm{ppm}$ of ozone was generated by flowing $1 \mathrm{~L} / \mathrm{min}$ of dry air $(\mathrm{RH}=0.7 \%)$ through the NTP reactor. Ozone concentration was obtained via linear regression applied to the integration area (obtained by FTIR in the range of 1050 to $1000 \mathrm{~cm}^{-1}$ ) as a function of the ozone concentration obtained with an ozone monitor (Teledyne API's model 465M). Ozone decomposition tests were carried out for $5 \mathrm{~h}$ at atmospheric pressure and room temperature $\left(20^{\circ} \mathrm{C}\right)$ over $0.05 \mathrm{~g}$ of catalyst mixed with $1 \mathrm{~g}$ of SiC (EMB 45053 Prolabo, $0.150 \mathrm{~mm}$ ). The ozone conversion efficiency was calculated using the following equation:

$$
\mathrm{O}_{3} \text { conversion }=\frac{\left[\mathrm{O}_{3}\right] \text { in }-\left[\mathrm{O}_{3}\right] \text { out }}{\left[\mathrm{O}_{3}\right] \text { in }} \times 100
$$

where $\left[\mathrm{O}_{3}\right]$ in and $\left[\mathrm{O}_{3}\right]$ out were the ozone concentration introduced in the reactor and that measured at the exit of the catalytic reactor, respectively.

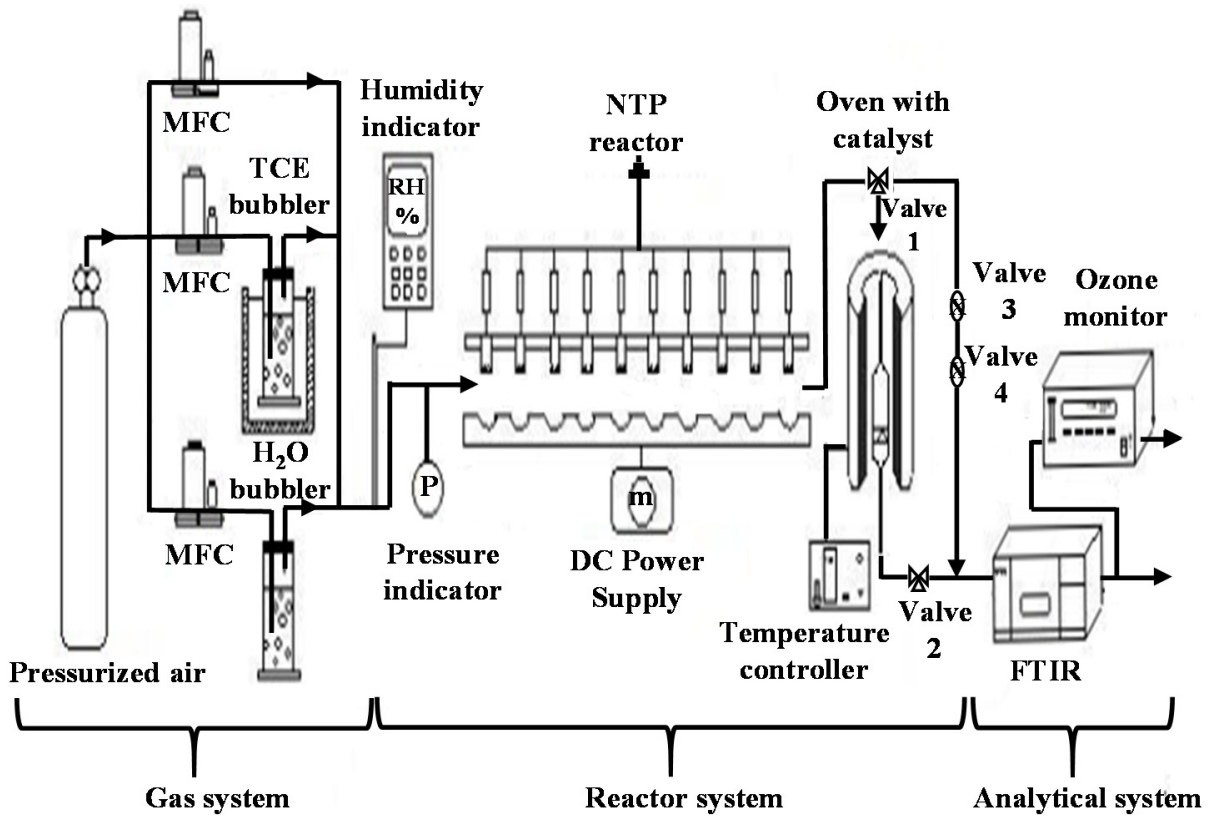

Figure 14. Schematic diagram of the experimental setup.

\subsection{Post-Plasma Catalysis for TCE Abatement}

Trichloroethylene (TCE; 99.99\% purity, ACROS, Merelbeke, Belgium) was evaporated by bubbling dry $(\mathrm{RH}=0.7 \%)$ or moist air $(\mathrm{RH}=15 \%)$ into a saturator and then introduced into the plasma reactor after being diluted with air (Figure 14). The total flow rate and TCE concentration in air were maintained at $1 \mathrm{~L} / \mathrm{min}$ and $150 \mathrm{ppmv}$, respectively, using mass flow controllers (MFCs; El-Flow, Bronkhorst, Bethlehem, PA, USA) the different experimental conditions are listed in Table 4. A 10-pin-to-plate plasma reactor configuration was used, working in a negative DC corona discharge. A total of $0.1 \mathrm{~g}$ of catalyst diluted in $1 \mathrm{~g}$ of $\mathrm{SiC}$ and placed in a quartz reactor was activated for $1 \mathrm{~h}$ in dry air $(0.2 \mathrm{~L} / \mathrm{min})$ at $100{ }^{\circ} \mathrm{C}$ and maintained at this temperature during the test. 
Table 4. Experimental conditions for the PPC tests.

\begin{tabular}{cc}
\hline Air source & Air liquid, Alphagaz 1 \\
Flow rate & $1 \mathrm{~L} / \mathrm{min}$ \\
Relative humidity (RH) & $0.7 \% / 15 \%$ \\
Energy density & $150 \mathrm{~J} / \mathrm{L}$ \\
Initial TCE concentration & $150 \mathrm{ppmv}$ \\
Catalyst & $\mathrm{Ce}_{0.01} \mathrm{Mn}-400$ and $\mathrm{Ce}_{0.01} \mathrm{Mn}-\mathrm{AT}$ \\
Activation conditions & $0.1 \mathrm{~g}$ of catalyst mixed with $1 \mathrm{~g}$ of $\mathrm{SiC}$ \\
Catalyst temperature & $200 \mathrm{~mL} / \mathrm{min}, 100{ }^{\circ} \mathrm{C}$ for $1 \mathrm{~h}$ \\
\hline
\end{tabular}

The TCE abatement (conversion) efficiency was calculated from:

$$
\mathrm{TCE} \text { conversion }=\frac{[T C E] \text { in }-[\text { TCE }] \text { out }}{[\text { TCE }] \text { in }} \times 100
$$

where [TCE] in and [TCE] out were the inlet and outlet concentrations, respectively.

The $\mathrm{CO}_{2}, \mathrm{CO}$ and $\mathrm{CO}_{x}$ yields were calculated as follows:

$$
\begin{aligned}
& Y C O_{2}(\%)=\frac{\left[\mathrm{CO}_{2}\right] \text { out }}{2 x[\text { TCE }] \text { in }} \times 100 \\
& Y C O(\%)=\frac{[\text { CO }] \text { out }}{2 x[\text { TCE }] \text { in }} \times 100 \\
& Y C O_{x}(\%)=Y C O_{2}(\%)+Y C O(\%)
\end{aligned}
$$

An FTIR spectrometer (Bruker, Billerica, MA, USA, Vertex 70) equipped with a $20 \mathrm{~cm}$ optical path length, a window diameter of $45 \mathrm{~mm}$ and resolution of $4 \mathrm{~cm}^{-1}$ was used to analyze the gaseous species at the exit of the plasma reactor for plasma alone (reactive gas-flow bypassing the catalytic reactor) and at the exit of the catalytic reactor for PPC (reactive gas-flow passing through the catalytic reactor). This reactive gas was sampled 10 times at intervals of $30 \mathrm{~s}$ for plasma alone and sampled 60 times at intervals of $30 \mathrm{~s}$, and then 135 times at intervals of $120 \mathrm{~s}$, for PPC. The number of scans for each spectrum was 10 in both cases. In order to quantify the TCE, $\mathrm{CO}_{2}$ and $\mathrm{CO}$, the FTIR spectrometer was calibrated with a calibration mixture delivered by Air liquid. The band areas between 916-966 cm $\mathrm{cm}^{-1}$ (TCE), 2388-2287 $\mathrm{cm}^{-1}\left(\mathrm{CO}_{2}\right)$ and 2140-2071 cm-1 (CO) were integrated and a linear regression was applied to the integration area.

\section{Conclusions}

In this study, TCE abatement was investigated at $100{ }^{\circ} \mathrm{C}$ in nearly dry $(\mathrm{RH}=0.7 \%)$ and moist air $(\mathrm{RH}=15 \%)$ in a PPC configuration using a 10-pin-to-plate negative DC corona discharge NTP reactor and cerium-modified birnessites calcined at $400{ }^{\circ} \mathrm{C}$ or treated with nitric acid as catalysts. The plasma conditions were chosen in order to treat a low concentration of TCE (150 ppmv) and be as close as possible to industrial issues in terms of VOC concentration abatement. A stoichiometric ratio $\left(\left[\mathrm{O}_{3}\right] /[\mathrm{TCE}]_{0}\right)$ of 4 was adopted in order to take advantage of the efficient properties of the catalysts for $\mathrm{O}_{3}$ decomposition.

In these conditions, the TCE removal efficiency was $85 \%$ but the $\mathrm{CO}_{x}$ yield was only $46 \%$ for the NTP process alone. Adding a catalyst downstream of the NTP reactor enhanced the performances of the process in dry and humid air in terms of TCE removal efficiency and $\mathrm{CO}_{2}$ selectivity due to the ability of the catalyst to totally decompose ozone and generate surface active oxygen species able to oxidize the unreacted TCE and some of the polychlorinated by-products. The plasma-assisted $\mathrm{Ce}_{0.01} \mathrm{Mn}$-AT catalyst presented the best $\mathrm{CO}_{2}$ yield in dry air (58\%) at the beginning of the experiment, reaching $40 \%$ after $5 \mathrm{~h}$ with no production of DCAC and TCAD in hard experimental conditions, such as high GHSV of $600 \mathrm{~L} / \mathrm{g} \cdot \mathrm{h}$, with only $0.1 \mathrm{~g}$ of catalyst. In this configuration the formation of gaseous chlorinated by-products was minimized but not totally suppressed. Both catalysts 
exhibited good stability for TCE abatement, which means they were chlorine-tolerant. $\mathrm{Ce}_{0.01} \mathrm{Mn}$-AT was tested in moist air and was also stable over time, which means it is also water-tolerant.

Author Contributions: G.A. conducted all the experiments except the $\mathrm{O}_{3}$ decomposition tests, which were done by R.B., J.-M.G., R.M. and J.-F.L., who also supervised the work. G.A. wrote the first draft of the paper. G.A., J.-M.G., N.D.G., R.M. and J.-F.L. contributed to the data interpretation, the discussion, and the revision of the paper. Funding acquisition: J.-F.L. and R.M. All authors have read and agreed to the published version of the manuscript.

Funding: This research was supported by the European Program INTERREG V France-WallonieFlanders (FEDER) (DepollutAir). The Fonds Européen de Développement Régional (FEDER), CNRS, Région Nord Pas-de-Calais and Ministère de l'Education Nationale de l'Enseignement Supérieur et de la Recherche are acknowledged for funding for X-ray diffractometers. The Chevreul institute (FR 2638), Ministère de l'Enseignement Supérieur et de la Recherche and Région Hauts-de-France are acknowledged for their support of this work. This research was carried out in the French-Belgium Associated International Laboratory "Plasma \& Catalysis", supported by the universities of Lille and Ghent.

Data Availability Statement: All the results are present in the main content of article.

Acknowledgments: The authors thank Pardis Simon, Laurence Burylo and Jean-Charles Morin for their contribution to the XPS, XRD and IR-pyridine measurements, respectively.

Conflicts of Interest: The authors declare no conflict of interest.

\section{References}

1. Huang, B.; Lei, C.; Wei, C.; Zeng, G. Chlorinated Volatile Organic Compounds (Cl-VOCs) in Environment-Sources, Potential Human Health Impacts, and Current Remediation Technologies. Environ. Inter. 2014, 71, 118-138. [CrossRef] [PubMed]

2. Wu, C.; Schaum, J. Exposure Assessment of Trichloroethylene. Environ. Health Perspect. 2000, 108, 359-363. [CrossRef]

3. Doherty, R.E. A History of the Production and Use of Carbon Tetrachloride, Tetrachloroethylene, Trichloroethylene and 1,1,1Trichloroethane in the United States: Part 1-Historical Background; Carbon Tetrachloride and Tetrachloroethylene. Environ. Forensics 2000, 1, 69-81. [CrossRef]

4. Rusyn, I.; Chiu, W.A.; Lash, L.H.; Kromhout, H.; Hansen, J.; Guyton, K.Z. Trichloroethylene: Mechanistic, Epidemiologic and Other Supporting Evidence of Carcinogenic Hazard. Pharmacol. Ther. 2014, 141, 55-68. [CrossRef] [PubMed]

5. Holzer, F.; Kopinke, F.D.; Roland, U. Influence of Ferroelectric Materials and Catalysts on the Performance of Non-Thermal Plasma (NTP) for the Removal of Air Pollutants. Plasma Chem. Plasma Process. 2005, 25, 595-611. [CrossRef]

6. Schiavon, M.; Torretta, V.; Casazza, A.; Ragazzi, M. Non-Thermal Plasma as an Innovative Option for the Abatement of Volatile Organic Compounds: A Review. Water Air Soil Pollut. 2017, 228, 388. [CrossRef]

7. Thevenet, F.; Sivachandiran, L.; Guaitella, O.; Barakat, C.; Rousseau, A. Plasma-Catalyst Coupling for Volatile Organic Compound Removal and Indoor Air Treatment: A Review. J. Phys. D Appl. Phys. 2014, 47, 224011. [CrossRef]

8. Chen, H.L.; Lee, H.M.; Chen, S.H.; Chang, M.B.; Yu, S.J.; Li, S.N.I. Removal of Volatile Organic Compounds by Single-Stage and Two-Stage Plasma Catalysis Systems: A Review of the Performance Enhancement Mechanisms, Current Status, and Suitable Applications. Environ. Sci. Technol. 2009, 43, 2216-2227. [CrossRef]

9. Subrahmanyam, C.; Renken, A.; Kiwi-Minsker, L. Catalytic Non-Thermal Plasma Reactor for Abatement of Toluene. Chem. Eng. J. 2010, 160, 677-682. [CrossRef]

10. Wu, J.; Xia, Q.; Wang, H.; Li, Z. Catalytic Performance of Plasma Catalysis System with Nickel Oxide Catalysts on Different Supports for Toluene Removal: Effect of Water Vapor. App. Catal. B Environ. 2014, 156-157, 265-272. [CrossRef]

11. Tu, X.; Gallon, H.J.; Whitehead, J.C. Electrical and Spectroscopic Diagnostics of a Single-Stage Plasma-Catalysis System: Effect of Packing with $\mathrm{TiO}_{2}$. J. Phys. D Appl. Phys. 2011, 44, 482003. [CrossRef]

12. Sultana, S.; Ye, Z.; Veerapandian, S.K.P.; Löfberg, A.; De Geyter, N.; Morent, R.; Giraudon, J.M.; Lamonier, J.F. Synthesis and Catalytic Performances of K-OMS-2, Fe/K-OMS-2 and Fe-K-OMS-2 in Post Plasma-Catalysis for Dilute TCE Abatement. Catal. Today 2018, 307, 20-28. [CrossRef]

13. Veerapandian, S.K.P.; Ye, Z.; Giraudon, J.-M.; De Geyter, N.; Morent, R.; Lamonier, J.-F. Plasma Assisted Cu-Mn Mixed Oxide Catalysts for Trichloroethylene Abatement in Moist Air. J. Hazar. Mater. 2019, 379, 120781. [CrossRef]

14. Liu, Y.; Zhang, P. Catalytic Decomposition of Gaseous Ozone over Todorokite-Type Manganese Dioxides at Room Temperature: Effects of Cerium Modification. Appl. Catal. A Gen. 2017, 530, 102-110. [CrossRef]

15. Ma, J.; Wang, C.; He, H. Transition Metal Doped Cryptomelane-Type Manganese Oxide Catalysts for Ozone Decomposition. Appl. Catal. B Environ. 2017, 201, 503-510. [CrossRef]

16. Li, X.; Ma, J.; Yang, L.; He, G.; Zhang, C.; Zhang, R.; He, H. Oxygen Vacancies Induced by Transition Metal Doping in $\gamma-\mathrm{MnO}_{2}$ for Highly Efficient Ozone Decomposition. Environ. Sci. Technol. 2018, 52, 12685-12696. [CrossRef] [PubMed] 
17. Ma, J.; Li, X.; Zhang, C.; Ma, Q.; He, H. Novel CeMn ${ }_{a} \mathrm{O}_{\mathrm{x}}$ Catalyst for Highly Efficient Catalytic Decomposition of Ozone. Appl. Catal. B Environ. 2020, 264, 118498. [CrossRef]

18. Tang, X.; Li, Y.; Huang, X.; Xu, Y.; Zhu, H.; Wang, J.; Shen, W. $\mathrm{MnO}_{\mathrm{x}}-\mathrm{CeO}_{2}$ Mixed Oxide Catalysts for Complete Oxidation of Formaldehyde: Effect of Preparation Method and Calcination Temperature. Appl. Catal. B Environ. 2006, 62, 265-273. [CrossRef]

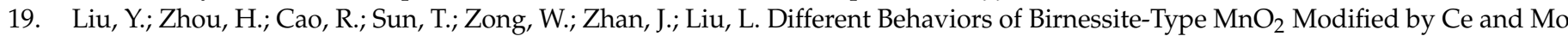
for Removing Carcinogenic Airborne Benzene. Mater. Chem. Phys. 2019, 221, 457-466. [CrossRef]

20. Chen, J.; Chen, X.; Yan, D.; Jiang, M.; Xu, W.; Yu, H.; Jia, H. A Facile Strategy of Enhancing Interaction between Cerium and Manganese Oxides for Catalytic Removal of Gaseous Organic Contaminants. Appl. Catal. B Environ. 2019, 250, 396-407. [CrossRef]

21. Zhu, L.; Wang, J.; Rong, S.; Wang, H.; Zhang, P. Cerium Modified Birnessite-Type $\mathrm{MnO}_{2}$ for Gaseous Formaldehyde Oxidation at Low Temperature. Appl. Catal. B Environ. 2017, 211, 212-221. [CrossRef]

22. Liu, Y.; Yang, W.; Zhang, P.; Zhang, J. Nitric Acid-Treated Birnessite-Type $\mathrm{MnO}_{2}$ : An Efficient and Hydrophobic Material for Humid Ozone Decomposition. Appl. Surf. Sci. 2018, 442, 640-649. [CrossRef]

23. Gopi, T.; Swetha, G.; Chandra Shekar, S.; Ramakrishna, C.; Saini, B.; Krishna, R.; Rao, P.V.L. Catalytic Decomposition of Ozone on Nanostructured Potassium and Proton Containing $\alpha-\mathrm{MnO}_{2}$ catalysts. Catal. Comm. 2017, 92, 51-55. [CrossRef]

24. Lin, F.; Zhang, Z.; Li, N.; Yan, B.; He, C.; Hao, Z.; Chen, G. How to Achieve Complete Elimination of Cl-VOCs: A Critical Review on Byproducts Formation and Inhibition Strategies during Catalytic Oxidation. Chem. Eng. J. 2021, 404, 126534. [CrossRef]

25. Abedi, K.; Ghorbani-Shahna, F.; Jaleh, B.; Bahrami, A.; Yarahmadi, R.; Haddadi, R.; Gandomi, M. Decomposition of Chlorinated Volatile Organic Compounds (CVOCs) Using NTP Coupled with $\mathrm{TiO}_{2} / \mathrm{GAC}, \mathrm{ZnO} / \mathrm{GAC}$, and $\mathrm{TiO}_{2}-\mathrm{ZnO} / \mathrm{GAC}$ in a PlasmaAssisted Catalysis System. J. Electrost. 2015, 73, 80-88. [CrossRef]

26. Drits, V.A.; Silvester, E.; Gorshkov, A.I.; Manceau, A. Structure of Synthetic Monoclinic Na-Rich Birnessite and Hexagonal Birnessite; I, Results from X-Ray Diffraction and Selected-Area Electron Diffraction. Am. Mineral. 1997, 82, 946-961. [CrossRef]

27. Gaillot, A.-C. Caractérisation Structurale de La Birnessite: Influence Du Protocole de Synthèse. Ph.D. Thesis, Université Joseph-Fourier-Grenoble I, Grenoble, France, 2002.

28. Villalobos, M.; Lanson, B.; Manceau, A.; Toner, B.; Sposito, G. Structural Model for the Biogenic Mn Oxide Produced by Pseudomonas Putida. Am. Mineral. 2006, 91, 489-502. [CrossRef]

29. Li, L.; Zhang, P.; Cao, R. Porous Manganese Oxides Synthesized with Natural Products at Room Temperature: A Superior Humidity-Tolerant Catalyst for Ozone Decomposition. Catal. Sci. Technol. 2020, 10, 2254-2267. [CrossRef]

30. Cao, R.; Zhang, P.; Liu, Y.; Zheng, X. Ammonium-Treated Birnessite-Type $\mathrm{MnO}_{2}$ to Increase Oxygen Vacancies and Surface Acidity for Stably Decomposing Ozone in Humid Condition. Appl. Surf. Sci. 2019, 495, 143607. [CrossRef]

31. Liu, Y.; Zhou, H.; Cao, R.; Liu, X.; Zhang, P.; Zhan, J.; Liu, L. Facile and Green Synthetic Strategy of Birnessite-Type MnO2 with High Efficiency for Airborne Benzene Removal at Low Temperatures. Appl. Catal. B Environ. 2019, 245, 569-582. [CrossRef]

32. De Rivas, B.; López-Fonseca, R.; González-Velasco, J.R.; Gutiérrez-Ortiz, J.I. On the Mechanism of the Catalytic Destruction of 1,2-Dichloroethane over Ce/Zr Mixed Oxide Catalysts. J. Mol. Catal. A Chem. 2007, 278, 181-188. [CrossRef]

33. Eren, E.; Gumus, H.; Eren, B.; Sarihan, A. Surface Acidity of H-Birnessite: Infrared Spectroscopic Study of Formic Acid Decomposition. Spectrosc. Lett. 2013, 46, 60-66. [CrossRef]

34. Tang, X.; Li, J.; Sun, L.; Hao, J. Origination of $\mathrm{N}_{2} \mathrm{O}$ from $\mathrm{NO}$ Reduction by $\mathrm{NH}_{3}$ over $\beta-\mathrm{MnO}_{2}$ and $\alpha-\mathrm{Mn}_{2} \mathrm{O}_{3}$. Appl. Catal. B Environ. 2010, 99, 156-162. [CrossRef]

35. Sun, M.; Zhang, B.; Liu, H.; He, B.; Ye, F.; Yu, L.; Sun, C.; Wen, H. The Effect of Acid/Alkali Treatment on the Catalytic Combustion Activity of Manganese Oxide Octahedral Molecular Sieves. RSC Adv. 2017, 7, 3958-3965. [CrossRef]

36. Biesinger, M.C.; Payne, B.P.; Grosvenor, A.P.; Lau, L.W.M.; Gerson, A.R.; Smart, R.S.C. Resolving Surface Chemical States in XPS Analysis of First Row Transition Metals, Oxides and Hydroxides: Cr, Mn, Fe, Co and Ni. Appl. Surf. Sci. 2011, 257, 2717-2730. [CrossRef]

37. Galakhov, V.R.; Demeter, M.; Bartkowski, S.; Neumann, M.; Ovechkina, N.A.; Kurmaev, E.Z.; Lobachevskaya, N.I.; Mukovskii, Y.M.; Mitchell, J.; Ederer, D.L. Mn 3 s Exchange Splitting in Mixed-Valence Manganites. Phys. Rev. B 2002, 65, 113102. [CrossRef]

38. Santos, V.P.; Pereira, M.F.R.; Órfão, J.J.M.; Figueiredo, J.L. Catalytic Oxidation of Ethyl Acetate over a Cesium Modified Cryptomelane Catalyst. Appl. Catal. B Environ. 2009, 88, 550-556. [CrossRef]

39. Dhandapani, B.; Oyama, S.T. Gas Phase Ozone Decomposition Catalysts. Appl. Catal. B Environ. 1997, 11, 129-166. [CrossRef]

40. Li, W.; Oyama, S.T. Mechanism of Ozone Decomposition on a Manganese Oxide Catalyst. 2. Steady-State and Transient Kinetic Studies. J. Am. Chem. Soc 1998, 120, 9047-9052. [CrossRef]

41. Li, W.; Gibbs, G.V.; Oyama, S.T.; April, R.V. Mechanism of Ozone Decomposition on a Manganese Oxide Catalyst. 1. In Situ Raman Spectroscopy and Ab Initio Molecular Orbital Calculations. J. Am. Chem. Soc. 1998, 120, 9041-9046. [CrossRef]

42. Zhu, G.; Zhu, J.; Jiang, W.; Zhang, Z.; Wang, J.; Zhu, Y.; Zhang, Q. Surface Oxygen Vacancy Induced A-MnO 2 nanofiber for Highly Efficient Ozone Elimination. Appl. Catal. B Environ. 2017, 209, 729-737. [CrossRef]

43. Gopi, T.; Swetha, G.; Chandra Shekar, S.; Ramakrishna, C.; Saini, B.; Krishna, R.; Rao, P.V.L. Catalytic Decomposition of Gaseous Ozone over Manganese Dioxides with Different Crystal Structures. Catal. Comm. 2016, 189, 210-218.

44. Li, X.; Ma, J.; He, H. Recent Advances in Catalytic Decomposition of Ozone. J. Environ. Sci. 2020, 94, 14-31. [CrossRef] 
45. Vandenbroucke, A.M.; Dinh, M.T.N.; Giraudon, J.M.; Morent, R.; De Geyter, N.; Lamonier, J.F.; Leys, C. Qualitative ByProduct Identification of Plasma-Assisted TCE Abatement by Mass Spectrometry and Fourier-Transform Infrared Spectroscopy. Plasma Chem. Plasma Process. 2011, 31, 707-718. [CrossRef]

46. Vandenbroucke, A.M.; Morent, R.; De Geyter, N.; Leys, C. Decomposition of Trichloroethylene with Plasma-Catalysis: A Review. J. Adv. Oxid. Technol. 2011, 14, 165-175. [CrossRef]

47. Vandenbroucke, A.M.; Aerts, R.; Van Gaens, W.; De Geyter, N.; Leys, C.; Morent, R.; Bogaerts, A. Modeling and Experimental Study of Trichloroethylene Abatement with a Negative Direct Current Corona Discharge. Plasma Chem. Plasma Process. 2015, 35, 217-230. [CrossRef]

48. Vandenbroucke, A.M.; Nguyen Dinh, M.T.; Nuns, N.; Giraudon, J.-M.; De Geyter, N.; Leys, C.; Lamonier, J.-F.; Morent, R. Combination of Non-Thermal Plasma and $\mathrm{Pd} / \mathrm{LaMnO}_{3}$ for Dilute Trichloroethylene Abatement. Chem. Eng. J. 2016, 283, 668-675. [CrossRef]

49. Peyrous, R. The Effect of Relative Humidity on Ozone Production by Corona Discharge in Oxygen or Air-A Numerical SimulationPart II: Air. Ozone Sci. Eng. 1990, 12, 41-64. [CrossRef]

50. Chen, J.; Wang, P. Effect of Relative Humidity on Electron Distribution and Ozone Production by DC Coronas in Air. IEEE trans. Plasma Sci. 2005, 33, 808-812. [CrossRef]

51. Dinh, M.T.N.; Giraudon, J.-M.; Vandenbroucke, A.M.; Morent, R.; De Geyter, N.; Lamonier, J.-F. Post Plasma-Catalysis for Total Oxidation of Trichloroethylene over Ce-Mn Based Oxides Synthesized by a Modified "Redox-Precipitation Route". App. Catal. B Environ. 2015, 172, 65-72. [CrossRef]

52. Dinh, M.T.N.; Giraudon, J.M.; Lamonier, J.F.; Vandenbroucke, A.; De Geyter, N.; Leys, C.; Morent, R. Plasma-Catalysis of Low TCE Concentration in Air Using $\mathrm{LaMnO}_{3}+\delta$ as Catalyst. Appl. Catal. B Environ. 2014, 147, 904-911. [CrossRef]

53. Vandenbroucke, A. Abatement of Volatile Organic Compounds by Combined Use of Non-Thermal Plasma and Heterogeneous catalysis. Ph.D. Thesis, University of Ghent, Ghent, Belgium, 2015. 